\title{
Süper emici polimer katkılı alkalilerle aktive edilen geopolimer harçların özellikleri
}

\author{
Properties of super absorbent polymer added alkali activated geopolymer \\ mortars
}

\author{
Umur Korkut Sevim ${ }^{1}$ (D), Müzeyyen Balçıkanlı Bankir ${ }^{2}$ (D), Büşra Sinem Genç 3 ,*iD \\ 1,2,3 İskenderun Teknik Üniversitesi, İnşaat Mühendisliği Bölümü, 31200, Hatay Türkiye
}

Öz

İskenderun Bölgesi'nde büyük miktarlarda açığa çıkan cürufların kullanımı sürdürülebilir geopolimer üretiminin sağlanması açısından önemlidir. Çalışma kapsamında Granüle Yüksek Fırın Cürufu (YFC) alkalilerle aktive edilmiş ve Süper Emici Polimer (SEP) ilavesi ile içten kürlenme etkisi gerçekleştirilerek kuruma çatlaklarının sayısı ve boyutunun azaltılması ile dayanım artışına katkı sağlanması araştırılmıştır. Sodyum poliakrilat esaslı SEP taneciklerine doyma derecesine kadar su emdirildikten sonra $50 \mathrm{gr}, 100 \mathrm{gr}$ ve $150 \mathrm{gr}$ olacak şekilde harç karıșımlarına eklenmiştir. Silikat modülü sabit olan (1.5) ve sodyum konsantrasyonu $\% 4, \% 6, \% 8$ olarak değiştirilen alkali çözeltiler ile YFC aktive edilmiştir. Alkalilerle aktive edilen SEP katkılı harçların taze halde yayılma çapı ve sertleşmiş halde eğilme ve basınç dayanımları ile su emme kapasiteleri belirlenmiştir. \%6 sodyum konsantrasyonunda 100 gr SEP içeren geopolimer numunelerin su emme kapasiteleri artarken basınç dayanımlarının kontrol numuneleri ile kıyaslanabilir olduğu belirlenmiștir. Deney sonuçlarına göre hem su emme kapasitesi (\%7.4) hemde basınç dayanımı (26.8 MPa) yüksek olan, $50 \mathrm{gr}$ SEP içeren ve $60^{\circ} \mathrm{C}^{\prime}$ de kür edilen $\mathrm{BS} 2 / 60^{\circ} \mathrm{C} / 50 \mathrm{gr}$ kodlu numunedir. YFC'nin alkali aktivasyonu ile dayanım kazanması ile SEP'in su emme kabiliyetinden faydalanılarak su emme oranı, dolaylı olarak boşluk miktarı yüksek geopolimer numuneler üretilmiştir.

Anahtar kelimeler: Süper emici polimer, İçten kürlenme, Geopolimer harç, Alkali aktivasyonu

\section{Giriș}

Tüm dünya ülkelerinde olduğu gibi ülkemizde de teknolojinin ve sanayinin hızlı bir şekilde gelişmesi, sağladığı avantajlarla birlikte sanayi üretimi sonrası açığa çıkan yan ürünlerin neden olduğu depolama ve çevresel sorunları da beraberinde getirmiştir. Bunun yanı sıra enerji tüketiminin de hızla artması ile beraber üretiminde ve kullanımında daha az enerjiye gereksinim duyulacak alternatif kaynaklara ihtiyaç duyulmuştur. Ülkemizde enerji tasarrufu konusundaki hassasiyetin artırılması ile bu konuda yapılacak olan çalışmalar için; daha detaylı araştırmaların yapılmasına olan gereksinim giderek artmıştır. Doğal kaynakların korunmasına duyulan ihtiyacın artması, çevresel

\begin{abstract}
Usage of slags which is released in large quantities in the Iskenderun Region is important in terms of providing sustainable geopolymer production. In this study, Granulated Blast Furnace Slag (YFC) was activated with alkalis and internal curing effect was investigated with addition of Super Absorbent Polymer (SEP), decreasing drying cracks and contribution to the development of strength were investigated. Water impressed sodium polyacrylate-based SEP to the degree of saturation was added 50 gr, 100 gr and 150 gr into geopolymer mixtures. YFC was activated with alkaline solutions with a constant silicate modulus (1.5) and sodium concentration changed to $4 \%, 6 \%, 8 \%$. The flow diameter, flexural and compressive strengths and water absorption capacities of the SEP added geopolymers were determined in fresh state of mortar. It was determined that the water absorption rate of $100 \mathrm{gr}$ SEP added geopolymer samples at $6 \%$ sodium concentration increased, while their compressive strength was comparable to the control samples. According to the results, it is a $\mathrm{BS} 2 / 60^{\circ} \mathrm{C} / 50 \mathrm{gr}$ sample with a high water absorption capacity $(7.4 \%)$ and a compressive strength (26.8 MPa), containing $50 \mathrm{gr}$ SEP and cured at $60^{\circ} \mathrm{C}$. Sustainable geopolymer samples with a high water absorption rate namely high void content were produced by making use of the water absorption ability of SEP with the strength of YFC with alkali activation.
\end{abstract}

Keywords: Super absorbent polymer, Internal curing, Geopolymer mortar, Alkali activation

açıdan alternatif nitelikte olabilecek malzeme arayışını arttırmakla birlikte özellikle endüstriyel yan ürünlerin değerlendirilmesi için araştırmalar yapılmaktadır. Üretimi esnasında $\mathrm{CO}_{2}$ salınımı açısından sorun teşkil eden Portland çimentosuna (PÇ) alternatif olarak Yüksek Fırın Cürufu (YFC), uçucu kül (UK), silika dumanı (SD) gibi yan ürünler farklı kimyasal ve fiziksel özelliklere sahip olduklarından katkı maddesi olarak kullanılmaktadır [1]. Yan ürün olarak açığa çıkan malzemelerden biri olan cüruf Türkiye'de bulunan 3 adet entegre demir-çelik fabrikasından sağlanmaktadır. Bunlardan biri olan İskenderun Demir-Çelik fabrikasında çelik üretimi sırasında çeşitli formlarda cüruflar açığa çıkmaktadır. Çıkan ürünün bir kısmı çimento

\footnotetext{
* Sorumlu yazar / Corresponding author, e-posta / e-mail: busragenc.mfbe19@iste.edu.tr (B. S. Genç) Geliș / Recieved: 23.11.2021 Kabul / Accepted: 24.01.2022 Yayımlanma / Published: 15.04.2022 doi: 10.28948/ngmuh.1027438
} 
üretiminde kullanılmakta ancak bir miktarı da farklı alanlarda kullanılmayı beklemektedir. Cüruflar günümüzde beton agregası olarak, klinker ile birlikte ögütülülerek çimento üretiminde, dolgu malzemesi olarak ve yol çalışmalarında temel malzemesi gibi birçok alanda kullanım alanı bulmaktadır [2]. YFC'nin alkali aktivasyonunda reaksiyonların hızlanması için sıcaklık kürü uygulaması yapılmaktadır. Fakat bu sıcaklığa maruz kalma esnasında harç numune yüzeyinde ve iç bölgelerinde mikro çatlaklar meydana gelebilmekte, düşük dayanım ve yüksek geçirimliliğe sebebiyet vermektedir. Çalışma kapsamında hiç çimento içermeyen ve YFC'nin alkali aktivasyonu ile yüksek oranda hacim artışı yapabilme kabiliyeti olan SEP'nin farklı oranlarda kullanılması ile boşluk yapısının artırılması ve bünyesine aldığı su sayesinde içten kürlenmeyi sağlayan harç üretimleri yapılmıştır. Üretilen harç numunelerine iki tür kür uygulanmıştır. Birinci grup laboratuvar ortamında kür edilmiş, ikinci grup ise $60^{\circ} \mathrm{C}$ sicaklıktaki etüvde 4 saat bekletildikten sonra laboratuvar koşullarına alınmıştır. Böylece sıcaklık sebebi ile oluşan çatlakların etkisi gözlemlenebilmiştir.

$\mathrm{Bu}$ araştırmanın konusuyla ilgili olarak yapılmış önceki çalışmalar incelendiğinde; Chen vd. [3] tarafından SEP'ın cüruf bazlı geopolimerler üzerinde mekanik özellliklerini nasıl geliştirdiğini incelediği çalışmada; \%12 sabit aktivatör oranına sahip ve silikat modülü 1 olarak hazırlanan cüruflu harç numuneleri için 3 ve 28 günlük çekme-basınç mukavemetleri ölçülmüştür. Karışımlara SEP eklenmesinin cüruf bazlı geopolimerlerin mukavemeti üzerinde belirgin bir etkisinin olduğu ifade edilmiştir. 28 günlük periyottaki etkinin daha önemli olduğunu belirtmişlerdir. Sürenin uzamasıyla, SEP çökeltisindeki suyun, hidratasyon reaksiyonuna devam ettiği, böylece mukavemetin arttığı, bu nedenle test numunesinin 28 günlük basınç mukavemetinin referans numunesine yakın olduğu gözlemlenmiştir. Ancak SEP dozajının doğrusal olarak artmasıyla test numunesinin kopma mukavemetinin değişmediğini ifade etmişlerdir. Bunun sebebinin, aşırı SEP muhtevası olabileceği, bulamaç kıvamının çok yüksek olmasından dolayı kolay kalıplanmamasına neden olabileceği şeklinde açıklanmıştır. Al-Nasra tarafından yapılan çalışmada [4], SEP katkılı betonun 1S1 transfer özellikleri araştırılmıştır. Beton karışımında beton dayanımına göre optimum miktarda SEP kullanılmıştır. Çalışmada işlenebilirlik ve basınç dayanımı testleri yapılmıştır. Beton basınç dayanımı söz konusu olduğunda, SEP'nin çimentoya ağırlıç̧a \%0.11 oranında katılmasının en etkili oran olduğu bulunmuştur. SEP'nin beton karışımında kullanılması, iç kürleme işlemi nedeniyle beton dayanımını artırma potansiyeline sahiptir. Beton kürünün yeterli olmadığı durumlarda avantajlı hale gelebileceği belirtilmiștir. Beton karışımında aşırı miktarda SEP kullanımı, basınç dayanımı üzerinde önemli derecede olumsuz etkiye sahiptir. Bu tür bir katkı kullanılarak beton stabilitesinin ve betonda meydana gelebilecek ayrışma olasılıklarını azalttığı durumlarda jelin büyük agregalara yastıklama sağlayabileceği ve donma direnci, su genleşmesi ile oluşan hidrolik basıncın absorbe edilebileceği belirtilmiştir. Beton karışımında SEP kullanılarak betonun 1S1 yalıtım özelliklerinin önemli ölçüde iyileştirilebileceği açıklanmıştır. Al-Nasra ve Daoud tarafından yapılan çalışmada [5], betonda SEP kullanımının taze ve sertleşmiş betonun özellikleri üzerinde birçok olumlu etkiye sahip olduğu kanıtlanmıştır. SEP'nin betona katkıda bulunabileceği en büyük iyileştirmelerden birinin, dahili su kaynağı sağlamak olduğu ifade edilmiştir. Bu dahili su kaynağı, beton son prizini aldıktan sonra dahili kürleme ajanı görevi görür. Aynı zamanda SEP, beton taze halde iken nispeten daha yavaş bir hızda su salmaktadır. SEP ayrıca beton kütlede ilave boşluklar oluşturur. $\mathrm{Bu}$ boşluklar beton dayanımını olumsuz etkilerken betonun işlenebilirliğini ve yerleştirilebilirliğini iyileştirerek, betonun donma çözülme döngülerine duyarlılığını azaltarak ve beton stabilitesini artırarak beton performansını iyileştirir. Manzur vd. [6] gelişmekte olan ülkelerde, dayanıklılık sorunları olan zayıf betonlar ile yapı inşaa edilmesi ve bunun dişında suyun bulunmaması veya vasıflı işçinin olmaması nedeniyle uygun harici sertleştirme sürecini sürdürmek zor olduğundan, dâhili sertleştirme yönteminin çözüm olabileceği düşüncesi ile çalışma yapmıştır. $\mathrm{Bu}$ amaçla içten kürlenmiş beton üretiminde SEP kullanılmıştır. SEP'in desorpsiyon izotermi, dahili kürleme ajanı olarak etkinliğini araştırmak için geliştirilmiştir. Desorpsiyon testinden, SEP'in suya daldırıldığında kendi ağırlığından büyük miktarda su emdiği ve daha sonra emilen suyu nispeten yüksek sicaklıkta ve düşük bağıl nemde serbest bırakabildiği belirtilmiştir. Test sonuçları, SEP ile dahili olarak kürlenmiş betonun, harici kürleme için ilave su tedarikinin olmadığı olumsuz kürleme koşullarına tabi tutulduğunda kontrol numunelerine kıyasla hem mukavemet hem de dayanıklılık açısından daha iyi performans gösterdiğini belirtmiştir. Mahmut vd. tarafindan yapılan çalışmada [7], çimento inceliğinde öğütülmüş Elazı̆̆ ferrokrom cürufunun $\mathrm{NaOH}-\mathrm{Na}_{2} \mathrm{SiO}_{3}$ kullanılarak 40, 65 ve $90{ }^{\circ} \mathrm{C}$ kür sıcaklığında alkalilerle aktive edilmiş harç üretim potansiyelinin araştırılması amaçlanmıştır. Kullanılan alkali aktivatörler 6, 9 ve 12 mol olacak şekilde kullanılmış olup aktivasyon sıcaklıkları 1, 2 ve 4 gün süreyle uygulanmıştır. Yapılan deneyler sonucunda çimento kullanmaksızın bağlayıcı olarak Elazığ ferrokrom cürufunun kullanıldığı 15 $\mathrm{MPa}$ dayanım değerinin üzerinde alkali aktive edilmiş harç üretilebileceği sonucuna varılmıştır. Ekinci vd. [8] yaptığı çalışmada, kullanılan ham madde ve alkali aktivatör özelliklerinin geopolimer hamurların basınç dayanımı özelliklerine etkilerini incelemişlerdir. Geopolimer hamur numunelerinde ham madde olarak $F$ sinıfi UK ve YFC kullanılmıştır. Birbiri içerisinde değişik oranlarda karışımları yapılarak hazırlanan ham maddeler, $\mathrm{Na}_{2} \mathrm{SiO}_{3}$ ve $\mathrm{NaOH}$ kullanılarak aktive edilmiştir. Üretilen numunelerin 7 ve 28. günlerdeki basınç dayanımı değerleri belirlenmiştir. Sonuçlara göre kullanılan ham madde ve alkali aktivatör özelliklerinin değişmesiyle birlikte basınç dayanımı değerlerinin büyük oranda değiştiği ifade edilmiştir. YFC ikame oranının artmasıyla basınç dayanımı değerlerinde ciddi artışlar gözlendiği belirtilmiştir. F sınıfı UK kullanılarak üretilen geopolimer örneklerinde ise laboratuvar şartlarında yüksek dayanım özelliklerine sahip olmaları için 1sıl küre ihtiyaç duyulduğu belirtilmiştir. Kullanılan ham madde tipinden bağımsız olarak, $\mathrm{Na}_{2} \mathrm{SiO}_{3}$ ile aktive edilen tüm örnekler, 28 günlük nihai dayanımının $\% 85$ 'den 
fazlasını ilk 7 gün içerisinde kazanıldığı belirtilmiştir. Bunun yanı sıra maksimum basınç dayanımının elde edilmesi için kullanılması gereken optimum $\mathrm{NaOH}$ konsantrasyonunun, bağlayıcı içeriğine bağlı olarak değişiklik gösterdiği saptanmıştır. Ziming He vd. tarafindan yapılan çalışmada [9] SEP ile modifiye edilmiş çimento esaslı kompozitlerin işlenebilirliğini ve mikro yapılarını inceleyerek SEP'in çimento esaslı malzemelerin reolojik özellikleri, mekanik özellikleri, büzülme, kendi kendini iyileştirme ve dayanıklılığı üzerindeki etkilerini araştırmışlardır. Çalışmaya göre SEP'in çimento hidratasyonunu destekleyebildiği, suyu serbest bıraktıktan sonra çimentolu matris içinde çok sayıda boşluk bıraktığı belirtilmiştir. SEP ilavesinin, çimentolu kompozitlerin otojen büzülmesini önemli ölçüde azaltabileceği ve sertleşmiş çimentolu matriste çatlak oluşumunun SEP'in su emmesi ve şişmesi nedeniyle iyileşebileceği ifade edilmiştir. Ayrıca, SEP'lerin çimento esaslı kompozitlerde homojen olarak dağılarak boşluklar bırakabileceği, böylece matrisin donma direncini iyileştirebileceği belirtilmiştir. Elibol'un [10] yaptığı çalışmada, belirli su/bağlayıcı oranında YFC'nin farklı alkalilerle aktive edilmesi ile üretilen numunelerin basınç dayanımları incelenmiştir. $\mathrm{Na}_{2} \mathrm{SiO}_{3}$, sodyum karbonat $\left(\mathrm{Na}_{2} \mathrm{CO}_{3}\right)$ ve $\mathrm{NaOH}$ alkalilerinin etkilerini karşılaştırabilmek için aynı $\mathrm{Na}$ konsantrasyonunda harçlar üretilmiştir. Harçların 7, 28 ve 90 günlük eğilme dayanımı ve basınç dayanımı incelendiğinde, sadece çimento ile üretilen şahit numuneye en yakın mekanik dayanımı \%100 YFC ile üretilip, $\mathrm{NaOH}$ ile aktive edilen harcin gösterdiği belirlenmiştir. Çalışmada üretilen harçların 7 ve 28 günlük basınç dayanımlarına bakılarak en uygun $\mathrm{Na}$ konsantrasyonunun $\% 5$ olduğunu belirtilmiştir. Ayrıca ilk değerlendirmelerde alkalilerle aktive edilen harçların 7 günlük basınç dayanımlarının düşük olduğu gözlenmiştir. Erken yaş dayanımını artırmak için harç numuneler ilk 3 ve 7 gün sıcak kür suyunda bekletilmiştir. Sıcaklıkları $40^{\circ} \mathrm{C}, 60$ ${ }^{\circ} \mathrm{C}$ ve $80^{\circ} \mathrm{C}$ ile değişen kür havuzlarında bekletilen numunelerin basınç dayanımları daha önce $20^{\circ} \mathrm{C}$ ' de kürlenen numunelerle karşılaştırılmıştır. Sıcaklık seviyesi ve sıcak kür havuzunda bekletilme süreleriyle doğru orantılı olarak basınç dayanımlarının arttığı ifade edilmiştir.

YFC'nin alkali aktivasyonu esnasında sıcaklık kürü etkisi ile suyun buharlaşıp bünyeden uzaklaşması neticesinde çok sayıda yüzey çatlaklarının oluştuğu yapılan literatür çalışmaları [11] ve deneysel ön çalışmalar ile belirlenmiştir. $\mathrm{Bu}$ çatlaklar geopolimerin dayanım ve dayanıklılık kaybına sebebiyet vermektedir. Bu nedenle çalışma kapsamında içten sürekli kürlenmeyi sağlayarak ani kurumayı önleyen, çatlak oluşumunu sınırlayan SEP katkısı kullanılarak geopolimer harç numuneler üretilmiş ve harçların performansı fiziksel ve mekanik özellikler açısından değerlendirilmiştir. YFC'nin alkali aktivasyonundan farklı ve ilave olarak SEP'in yüksek oranda su emme kabiliyetinden faydalanılarak hem geçirimliliği hemde dayanımı nispeten yüksek olan geopolimer harç numune üretimleri yapılmıştır.

\section{Materyal ve metot}

\subsection{Materyal}

$\mathrm{Bu}$ çalışmada; İskenderun Demir-Çelik Fabrikası yan ürünü olan YFC ile kırmataş, su, alkali aktivatör olarak sodyum silikat $\left(\mathrm{Na}_{2} \mathrm{SiO}_{3}\right)$ ve sodyum hidroksit $(\mathrm{NaOH})$ ve ek olarak süper emici malzeme olan sodyum poliakrilat $\left(\mathrm{C}_{3} \mathrm{H}_{3} \mathrm{NaO}_{2}\right)_{\mathrm{n}}$ kullanılmıştır. YFC aktivasyonu için; üretim sırasında Na konsantrasyonu \% $\%, \% 6, \% 8$ oranlarında; silikat modülü de 1.5 oranına sahip alkali çözeltiler hazırlanmıştır. Karışım oranları ile ilgili detaylı bilgi Tablo 3 'te verilmiştir. MH-1, MH-2, MH-3 olarak isimlendirilen numuneler; YFC, agrega, su, $\mathrm{NaOH}$ ve $\mathrm{Na}_{2} \mathrm{SiO}_{3}$ kullanilarak hazırlanan referans numunelerini ifade etmektedir. BS-1, BS-2, BS-3 numuneleri ise SEP eklenen numuneleri ifade etmektedir. Her karışımdan üretilen numuneler laboratuvar şartları (23 ${ }^{\circ} \mathrm{C}$ ) ve $60^{\circ} \mathrm{C}$ olmak üzere iki farklı grupta kür edilmiştir. 24 farklı harç karışımı hazırlanmış olup her karışımdan üçer numune test edilmiştir ve toplamda 72 adet numune üretilmiştir.

\subsubsection{Yüksek firın cürufu}

Çalışmada kullanılan YFC İskenderun Demir-Çelik Fabrikasından temin edilmiştir. YFC'nin yoğunluğu 2.89 $\mathrm{g} / \mathrm{cm}^{3}$ ve Blaine inceliği $540 \mathrm{~m}^{2} / \mathrm{kg}$ 'dır. YFC'nin kimyasal özellikleri Tablo 1' de detaylı olarak gösterilmiştir.

Tablo 1. Yüksek firın cürufunun kimyasal kompozisyonu

\begin{tabular}{lc}
\hline Bileşen & Analiz Sonuçları (\%) \\
\hline $\mathrm{SiO}_{2}$ & 43.08 \\
$\mathrm{Al}_{2} \mathrm{O}_{3}$ & 10.93 \\
$\mathrm{Fe}_{2} \mathrm{O}_{3}$ & 0.74 \\
$\mathrm{CaO}$ & 36.24 \\
$\mathrm{MgO}$ & 6.10 \\
$\mathrm{SO}_{3}$ & 0.60 \\
$\mathrm{~S}^{-2}$ & 0.51 \\
$\mathrm{Na}_{2} \mathrm{O}$ & 0.28 \\
$\mathrm{~K}_{2} \mathrm{O}$ & 0.74 \\
$\mathrm{Na}_{2} \mathrm{O}+0.658 \mathrm{~K}_{2} \mathrm{O}$ & 0.76 \\
$\mathrm{~K}_{12 d}$ ırma Kayb1 & 0.01 \\
Serbest Kireç & - \\
\hline
\end{tabular}

\subsubsection{Alkali aktivatörler}

$\mathrm{Bu}$ çalışmada $\mathrm{Na}_{2} \mathrm{SiO}_{3}$ ve $\mathrm{NaOH}$ kullanılmıştır. $\mathrm{Bu}$ alkalilerin kimyasal ve fiziksel özellikleri Tablo 2'de detaylı olarak verilmiştir. $\mathrm{NaOH}$ katı formda ve beyaz renkli, suda iyi çözünen bir kimyasaldır. Şekil 1-c'de kullanılan $\mathrm{NaOH}$ gösterilmiştir. Cam suyu olarak adlandırılan $\mathrm{Na}_{2} \mathrm{SiO}_{3}$ ise katı ve sıvı renksiz veya yeşil renkte olabilmektedir. Suda çözündüğünde Şekil 1-d 'de olduğu gibi şurupsu, koyu renkte bir sıvı şeklinde görülmektedir.

\subsubsection{Sodyum poliakrilat}

Süper emici olarak da adlandırılan sodyum poliakrilatın su emiciliği kendi ağırlığının yaklaşık 200-300 katı kadardır. Şekil 1.e'de kullanılan SEP gösterilmiştir. 
Tablo 2. Sodyum silikat ve Sodyum hidroksitin fiziksel ve kimyasal kompozisyonu [11]

\begin{tabular}{|c|c|c|}
\hline & Fiziksel ve Kimyasal Özellikleri & Analiz Sonuçları \\
\hline \multirow[t]{7}{*}{ Sodyum Silikat } & Görünüşü & Renksiz, berrak, kıvamlı siv1 \\
\hline & Molekül Ağırlığı $\left(\mathrm{SiO}_{2} / \mathrm{Na}_{2} \mathrm{O}\right)$ & 3.19 \\
\hline & Molekül Modeli $\left(\mathrm{SiO}_{2} / \mathrm{Na}_{2} \mathrm{O}\right)$ & 3.30 \\
\hline & $20{ }^{\circ} \mathrm{C}$ & 39.4 \\
\hline & Yoğunluk & 1.373 \\
\hline & $\mathrm{Na}_{2} \mathrm{O}(\%)$ & 8.52 \\
\hline & $\mathrm{SiO}_{2}(\%)$ & 27.09 \\
\hline \multirow[t]{13}{*}{ Sodyum Hidroksit } & Toplam Alkalinite $(\mathrm{NaOH})(\mathrm{g} / \mathrm{kg})$ & $\geq 990$ \\
\hline & Sodyum Karbonat $\left(\mathrm{Na}_{2} \mathrm{CO}_{3}\right)(\mathrm{g} / \mathrm{kg})$ & $\leq 4$ \\
\hline & Sodyum Sülfat $\left(\mathrm{Na}_{2} \mathrm{SO}_{4}\right)(\mathrm{mg} / \mathrm{kg})$ & $\leq 80$ \\
\hline & Sodyum Klorit $(\mathrm{NaCl})(\mathrm{mg} / \mathrm{kg})$ & $\leq 200$ \\
\hline & Demir (Fe) (mg/kg) & $\leq 10$ \\
\hline & Civa $(\mathrm{Hg})(\mathrm{mg} / \mathrm{kg})$ & $\leq 0.1$ \\
\hline & Arsenik (As) (mg/kg) & $\leq 1$ \\
\hline & Kadmiyum $(\mathrm{Cd})(\mathrm{mg} / \mathrm{kg}$ & $\leq 1$ \\
\hline & Krom $(\mathrm{Cr} \quad(\mathrm{mg} / \mathrm{kg})$ & $\leq 1$ \\
\hline & Kurşun $(\mathrm{Pb})(\mathrm{mg} / \mathrm{kg})$ & $\leq 0.5$ \\
\hline & Antimon (Sb) (mg/kg) & $\leq 5$ \\
\hline & Selenyum (Se) (mg/kg) & $\leq 5$ \\
\hline & Nikel (Ni) (mg/kg) & $\leq 2$ \\
\hline
\end{tabular}

Tablo 3. Çalışmada uygulanan karışım tasarımı ( $1 \mathrm{dm}^{3}$ için karışım oranları )

\begin{tabular}{|c|c|c|c|c|c|c|c|c|c|c|c|}
\hline & $\begin{array}{r}\text { Silikat } \\
\text { Modülü }\end{array}$ & $\begin{array}{l}\begin{array}{l}\text { Numune } \\
\text { İsimleri }\end{array} \\
\end{array}$ & $\begin{array}{c}\begin{array}{c}\text { Sodyum } \\
\text { Konst. }\end{array} \\
\end{array}$ & $\begin{array}{c}\text { Deney } \\
\text { Sinıflandirma } \\
\end{array}$ & $\begin{array}{c}\text { Kür } \\
\text { Sıcaklığı }\end{array}$ & $\begin{array}{c}\text { YFC } \\
(\mathrm{gr})\end{array}$ & $\begin{array}{c}\text { Agrega } \\
(\mathrm{gr})\end{array}$ & $\begin{array}{l}\text { Su } \\
\text { (gr) }\end{array}$ & $\begin{array}{c}\mathrm{NaOH}( \\
\mathrm{gr})\end{array}$ & $\begin{array}{c}\mathbf{N a}_{2} \mathbf{S i o}_{3} \\
(\mathrm{gr})\end{array}$ & $\begin{array}{l}\text { SEP Oran- } \\
\text { lari (gr) }\end{array}$ \\
\hline \multirow{6}{*}{ 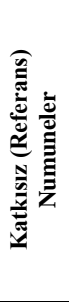 } & & \multirow{2}{*}{ MH-1 } & \multirow{2}{*}{4} & $\mathrm{MH}-1 / 23^{\circ} \mathrm{C}$ & $23^{\circ} \mathrm{C}$ & 520 & 1420 & 165 & 18 & 150 & 0 \\
\hline & & & & $\mathrm{MH}-1 / 60{ }^{\circ} \mathrm{C}$ & $60^{\circ} \mathrm{C}$ & 520 & 1420 & 165 & 18 & 150 & 0 \\
\hline & & \multirow{2}{*}{ MH-2 } & \multirow{2}{*}{6} & $\mathrm{MH}-2 / 23{ }^{\circ} \mathrm{C}$ & $23^{\circ} \mathrm{C}$ & 520 & 1420 & 117 & 27 & 223 & 0 \\
\hline & & & & $\mathrm{MH}-2 / 60{ }^{\circ} \mathrm{C}$ & $60^{\circ} \mathrm{C}$ & 520 & 1420 & 117 & 27 & 223 & 0 \\
\hline & & \multirow{2}{*}{ MH-3 } & \multirow{2}{*}{8} & $\mathrm{MH}-3 / 23{ }^{\circ} \mathrm{C}$ & $23^{\circ} \mathrm{C}$ & 520 & 1420 & 70 & 36 & 298 & 0 \\
\hline & & & & $\mathrm{MH}-3 / 60{ }^{\circ} \mathrm{C}$ & $60^{\circ} \mathrm{C}$ & 520 & 1420 & 70 & 36 & 298 & 0 \\
\hline \multirow{18}{*}{ 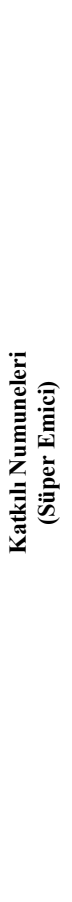 } & \multirow{18}{*}{1.5} & \multirow{6}{*}{ BS-1 } & \multirow{6}{*}{4} & $\mathrm{BS}-1 / 23^{\circ} \mathrm{C} /(50 \mathrm{gr})$ & \multirow{3}{*}{$23^{\circ} \mathrm{C}$} & 520 & 1420 & 165 & 18 & 150 & 50 \\
\hline & & & & $\mathrm{BS}-1 / 23^{\circ} \mathrm{C} /(100$ gr $)$ & & 520 & 1420 & 165 & 18 & 150 & 100 \\
\hline & & & & $\mathrm{BS}-1 / 23{ }^{\circ} \mathrm{C} /(150 \mathrm{gr})$ & & 520 & 1420 & 165 & 18 & 150 & 150 \\
\hline & & & & $\mathrm{BS}-1 / 60^{\circ} \mathrm{C} /(50 \mathrm{gr})$ & \multirow{3}{*}{$60^{\circ} \mathrm{C}$} & 520 & 1420 & 165 & 18 & 150 & 50 \\
\hline & & & & $\mathrm{BS}-1 / 60^{\circ} \mathrm{C} /(100 \mathrm{gr})$ & & 520 & 1420 & 165 & 18 & 150 & 100 \\
\hline & & & & $\mathrm{BS}-1 / 60^{\circ} \mathrm{C} /(150$ gr $)$ & & 520 & 1420 & 165 & 18 & 150 & 150 \\
\hline & & \multirow{6}{*}{ BS-2 } & \multirow{6}{*}{6} & $\mathrm{BS}-2 / 23^{\circ} \mathrm{C} /(50 \mathrm{gr})$ & \multirow{3}{*}{$23^{\circ} \mathrm{C}$} & 520 & 1420 & 117 & 27 & 223 & 50 \\
\hline & & & & $\mathrm{BS}-2 / 23{ }^{\circ} \mathrm{C} /(100 \mathrm{gr})$ & & 520 & 1420 & 117 & 27 & 223 & 100 \\
\hline & & & & $\mathrm{BS}-2 / 23{ }^{\circ} \mathrm{C} /(150 \mathrm{gr})$ & & 520 & 1420 & 117 & 27 & 223 & 150 \\
\hline & & & & $\mathrm{BS}-2 / 60^{\circ} \mathrm{C} /(50 \mathrm{gr})$ & \multirow{3}{*}{$60^{\circ} \mathrm{C}$} & 520 & 1420 & 117 & 27 & 223 & 50 \\
\hline & & & & $\mathrm{BS}-2 / 60^{\circ} \mathrm{C} /(100 \mathrm{gr})$ & & 520 & 1420 & 117 & 27 & 223 & 100 \\
\hline & & & & $\mathrm{BS}-2 / 60{ }^{\circ} \mathrm{C} /(150 \mathrm{gr})$ & & 520 & 1420 & 117 & 27 & 223 & 150 \\
\hline & & \multirow{6}{*}{ BS-3 } & \multirow{6}{*}{8} & $\mathrm{BS}-3 / 23^{\circ} \mathrm{C} /(50 \mathrm{gr})$ & \multirow{3}{*}{$23^{\circ} \mathrm{C}$} & 520 & 1420 & 70 & 36 & 298 & 50 \\
\hline & & & & $\mathrm{BS}-3 / 23^{\circ} \mathrm{C} /(100 \mathrm{gr})$ & & 520 & 1420 & 70 & 36 & 298 & 100 \\
\hline & & & & $\mathrm{BS}-3 / 23^{\circ} \mathrm{C} /(150 \mathrm{gr})$ & & 520 & 1420 & 70 & 36 & 298 & 150 \\
\hline & & & & $\mathrm{BS}-3 / 60{ }^{\circ} \mathrm{C} /(50$ gr $)$ & \multirow{3}{*}{$60^{\circ} \mathrm{C}$} & 520 & 1420 & 70 & 36 & 298 & 50 \\
\hline & & & & $\mathrm{BS}-3 / 60{ }^{\circ} \mathrm{C} /(100 \mathrm{gr})$ & & 520 & 1420 & 70 & 36 & 298 & 100 \\
\hline & & & & $\mathrm{BS}-3 / 60^{\circ} \mathrm{C} /(150 \mathrm{gr})$ & & 520 & 1420 & 70 & 36 & 298 & 150 \\
\hline
\end{tabular}




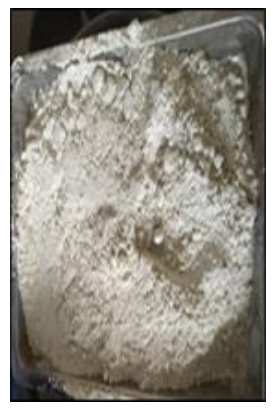

(a)

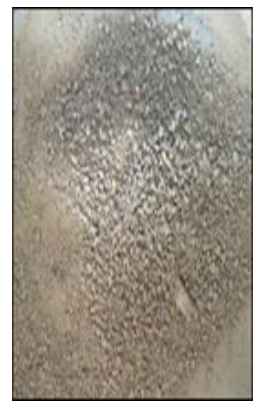

(b)

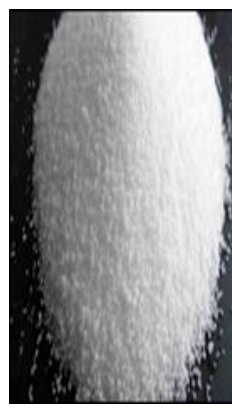

(c)

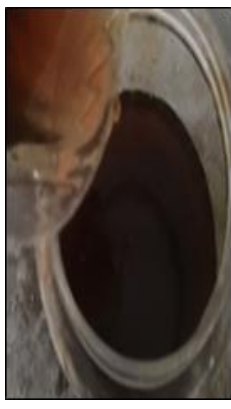

(d)

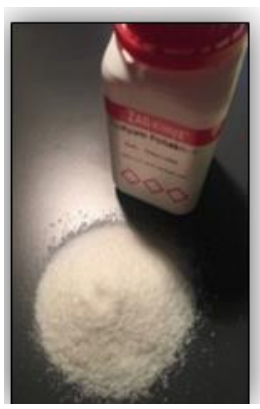

(e)

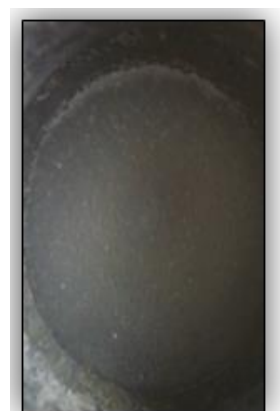

(f)

Şekil 1. a) Yüksek firın cürufu, b) Kırmataş c) Sodyum hidroksit d) Sodyum silikat e,f) Sodyum poliakrilat

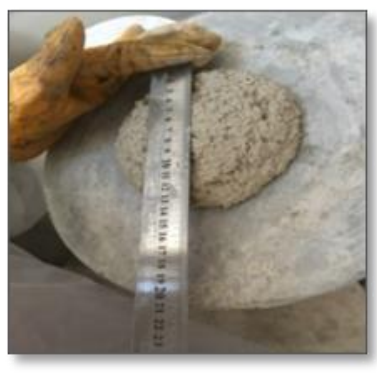

(a)

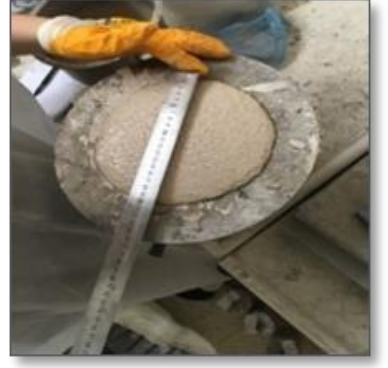

(b)

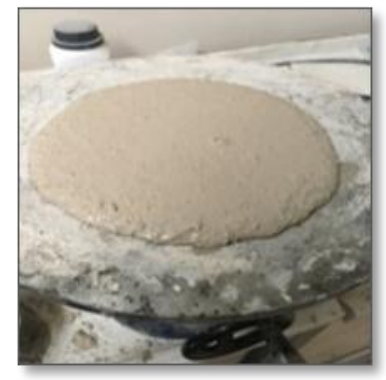

(c)

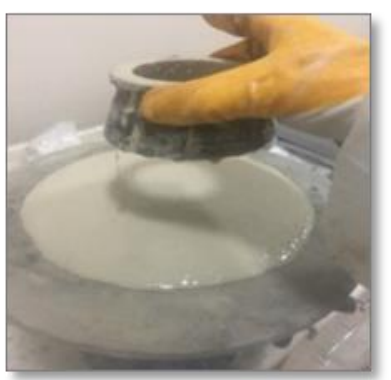

(d)

Şekil 2. Harç numunelerinin yayılma testi

\subsection{Metot}

Üretilen harçların alkali çözelti özellikleri literatür çalışmalarından edinilen bilgiler ışığında belirlenmiştir. ASTM C109'da [12] belirtilen çimento: agrega ve su oranına benzer şekilde YFC: agrega: alkali çözelti şeklinde sırası ile 1:2.75:0.485 olarak seçilmiştir. Harç üretiminde kullanılan alkali aktivatör çözeltideki $\mathrm{NaOH}$ konsantrasyonu mevcut $\mathrm{Na}_{2} \mathrm{SiO}_{3}$ çözeltisine ilaveten pelet haldeki NaOH'ın dışarıdan ilavesi ile tasarlanan derişime getirilmiştir. YFC'nin alkali aktivasyonu için silikat modülü ( $\mathrm{Si} / \mathrm{Na}$ oranı) 3 olan sodyum silikat $\left(\mathrm{Na}_{2} \mathrm{SiO}_{3}\right)$ çözeltisinin bünyesindeki sodyum konsantrasyonunu değiştirmek için dişardan ilave olarak \%99 saflıktaki $\mathrm{NaOH}$ ilave edilmiştir. Böylece alkali çözeltide bulunan sodyum derişimi istenilen Tablo 3'de belirtilen oranlara getirilmiştir. Süper emici poliakrilatı hazırlamak için öncelikle 10 gr SEP içerisine 1000 gr su eklenerek karışımın içerisindeki SEP'ın tamamen su ile dolması beklenmiştir. Suyu emen SEP malzeme doygun halde 50,100 ve 150 gr olacak şekilde tartılarak harç karışımına eklenmiştir. Homojen karışımın elde edilmesinin ardından hazırlanan harç karışımlarının kıvamını belirlemek için yayılma tablası testi yapılmıştır. Burada harç iki aşamalı olarak kesik koni şeklinde kalıba yerleştirilip üzeri düzeltildikten sonra $15 \mathrm{kez}$ düşürülerek yayılan taze haldeki harcın çapı $\mathrm{x}$ ve y doğrultusunda en geniş kısımları alınarak ölçülüp kaydedilmiştir.

Farklı harçların kıvamları Şekil 2'de gösterilmektedir. Üretilen harçlardan 40×40×160 mm boyutlarındaki kiriş numuneler üretilmiş ve bu numuneler üzerinde TS EN 1961'e [13] uygun şekilde eğilme ve basınç testleri yapılmıştır.
Harç numune üretimlerine ait fotoğraflar Şekil 3 ve Şekil 4'de gösterilmiștir. Hazırlanan kiriş numuneler 24 saat boyunca priz alması için kalıplarda bekletilmiştir. Daha sonra kalıptan çıkarılan numunelerden bir grubu $23{ }^{\circ} \mathrm{C}$ 'de laboratuvar ortamında, diğer grubu da $60{ }^{\circ} \mathrm{C}$ 'de 4 saat süre ile kür edilmiştir (Şekil 5).

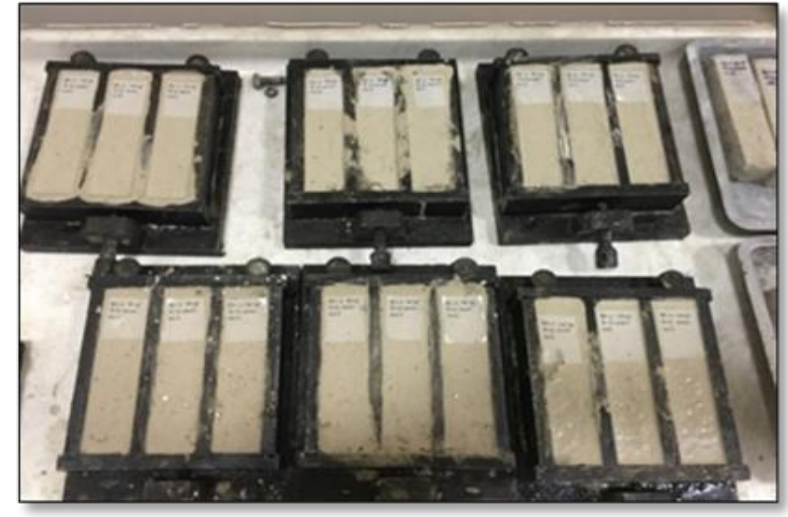

Şekil 3. Hazırlanan harç numuneleri

Eğilme ve basınç dayanımının yanı sıra boşluk miktarı hakkında fikir sahibi olmak için harç numunelerin su emme oranları da belirlenmiştir. Numunelerin mevcut ağırlıkları ( $\left.W_{\text {ortam }}\right), 24$ saat suda bekletilip yüzeyi kurutulduktan sonra doygun yüzey kuru ağırlıkları $\left(W_{d y k}\right)$ ve 24 saat etüvde tamamen kuruduktan sonraki ağırlıkları $\left(W_{k}\right)$ 
belirlenmiştir. Eşitlik (1)' deki eşitlik yardımı ile su emme kapasiteleri hesaplanarak sonuçlar değerlendirilmiştir.

Su Emme Oranı $(\%)=\frac{w_{d y k}-W_{k}}{w_{k}} \times 100[12]$

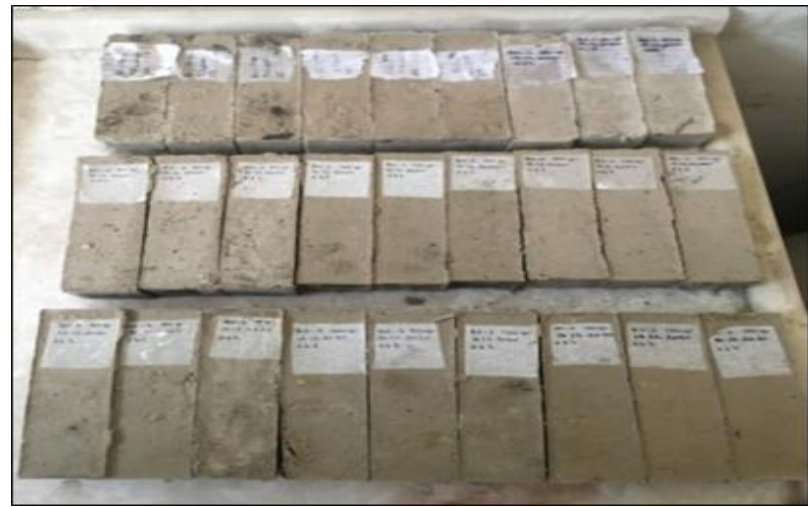

Şekil 4. Hazırlanan harç numuneleri

Uygulanan yük nedeni ile basma ve çekme kuvvetleri meydana geldiğinden numunelerde gözlemlenen eğilmenin ardından kırılma meydana gelmiştir. (Şekil 6). Her bir numune için aynı işlemlerin uygulanmasının ardından eğilme testi sonuçları $\mathrm{kN}$ olarak ölçülüp kaydedilmiştir. Numunelerin eğilme dayanımları Tablo 6' da verilmiştir.

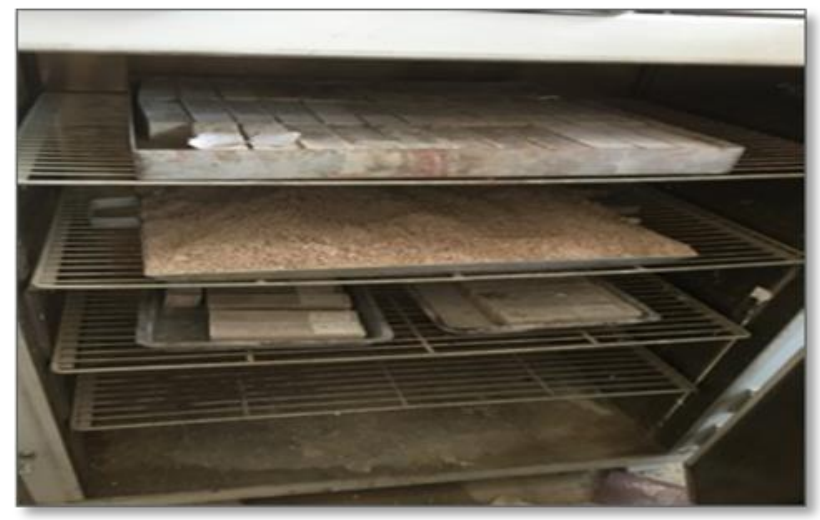

Şekil 5. Harç numunelere sıcaklık kürü uygulanması
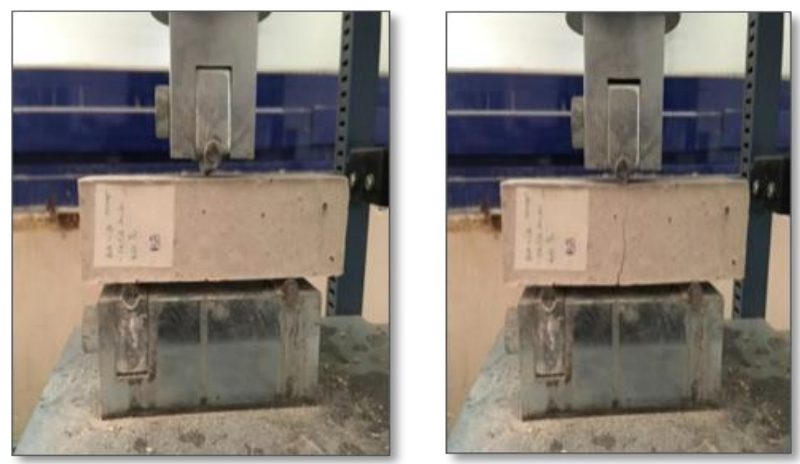

Şekil 6. Numunelerin eğilme deneyi
Eğilme deneyinde sonucunda iki parçaya ayrılan numuneler 40x40 mm press başlığı arasına Şekil 7'de görüleceği gibi yerleştirilip basınç testine tabii tutulmuştur (Şekil 8). Eğilme deneyinde 2 parçaya ayrılan numuneler üzerinde basınç testi uygulanmıştır. Numunelerin basınç dayanımları Tablo 7'de detaylı olarak verilmiştir.
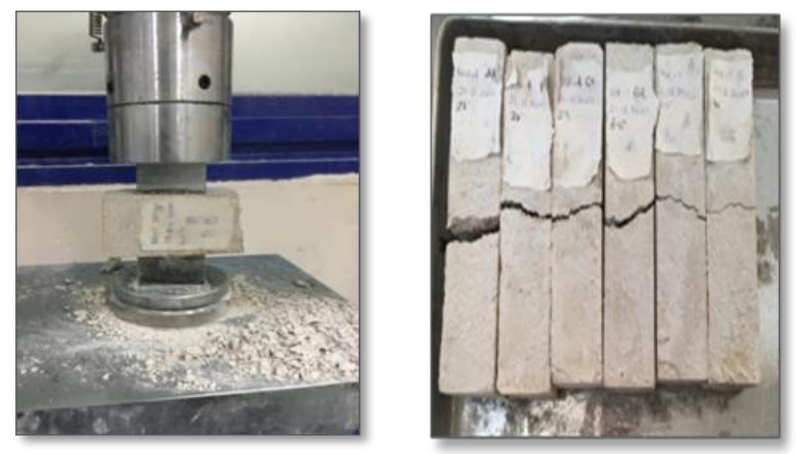

Şekil 7. Numunelere basınç yükü uygulanması
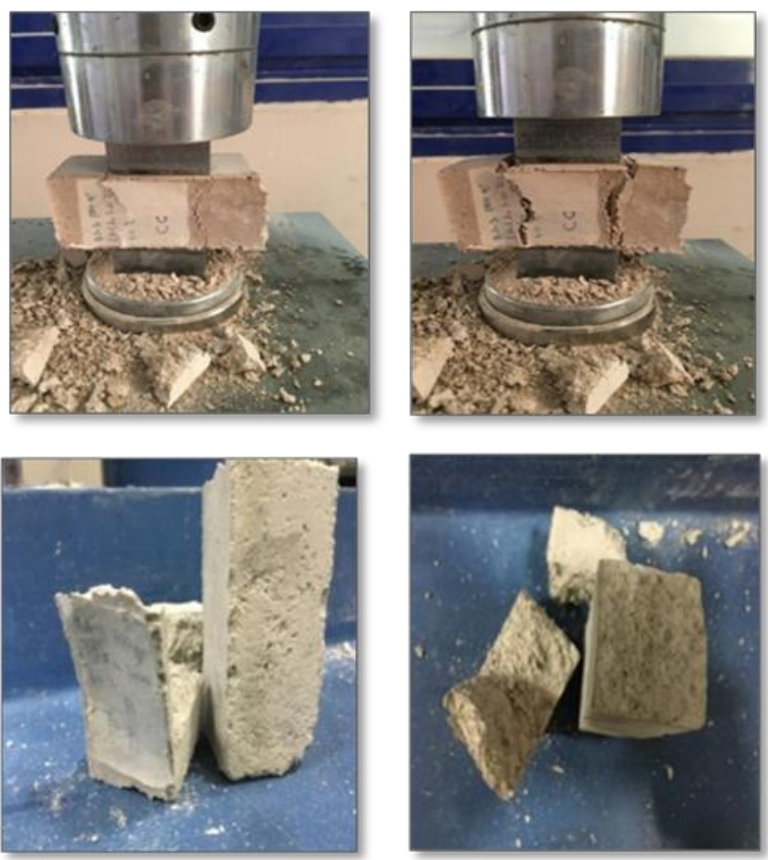

Şekil 8. Numunelerin basınç testi

\section{Bulgular ve tartışma}

\subsection{Yayılma tablasi deneyi}

Harç karışımlarının kıvamını belirlemek için taze harç yayılma tablasında $15 \mathrm{kez}$ düşürüldükten sonra $\mathrm{x}$ ve $\mathrm{y}$ doğrultusundaki yayılma değerleri ölçülmüş, aritmetik ortalaması alınmış ve sonuçlar Tablo 4 ve Şekil 9'da verilmiştir. Şekil 2'den görüldüğü üzere referans karışımının yayılma çapı düşük iken (Şekil 2-a), süper emici poliakrilat (SEP) miktarı arttıkça yayılma çapları da artış göstermiştir (Şekil 2-b,c,d). BS-3 (150 gr SEP)'i gösteren Şekil 2-d'de karışımında bulunan SEP miktarına bağlı yayılma çapı artmıştır. Benzer şekilde Al-Nasra ve Daoud tarafindan yapılan çalışmada [5] SEP katkılı betonda homojen olarak 
dağılmış küçük boşlukların olduğu ve daha kolay işlenebilir olduğu belirtilmiştir.

Tablo 4. Numunelerin yayılma çapları

\begin{tabular}{|c|c|c|}
\hline $\begin{array}{c}\text { Sodyum } \\
\text { konsantrasyonu } \\
(\%) \\
\end{array}$ & Harç numuneleri & $\begin{array}{c}\text { Yayılma } \\
\text { çapı (mm) }\end{array}$ \\
\hline \multirow{4}{*}{4} & MH-1 & 130 \\
\hline & BS-1 (50 gr SEP) & 175 \\
\hline & BS-1 (100 gr SEP ) & 185 \\
\hline & BS-1 (150 gr SEP ) & 236 \\
\hline \multirow{4}{*}{6} & MH-2 & 160 \\
\hline & BS-2 (50 gr SEP ) & 192.5 \\
\hline & BS-2 (100 gr SEP ) & 242.5 \\
\hline & BS-2 (150 gr SEP ) & 245 \\
\hline \multirow{4}{*}{8} & MH-3 & 145 \\
\hline & BS-3 (50 gr SEP ) & 205 \\
\hline & BS-3 (100 gr SEP ) & 240 \\
\hline & BS-3 (150 gr SEP ) & 292.5 \\
\hline
\end{tabular}

\subsection{Su emme oranl}

Karışım tasarımına uygun olarak hazırlanan numunelerin su emme oranları Tablo 5'te verilmiştir. Referans numuneleri olarak belirlenen yani içeriğinde hiç SEP bulunmayan MH-1, MH-2 ve MH-3 numunelerinde sodyum konsantrasyonun artışı ile su emme oranları azalmıştır. Harç içerisine eklenen SEP miktarı arttıkça su emme oranları artmıştır. YFC'nin bağlayıcılık özelliğinin artması için eklenen alkali aktivatör çözeltisindeki sodyum konsantrasyonunun artışı SEP katkılı numunelerin etkisini düşürmüştür. Şekil 10'dan görüldüğü üzere 50 gr SEP eklenmiş numuneler içerisinde BS1 numunelerinin su emme oranları yüksek iken, sodyum konsantrasyonu artan numunelerde (BS-2, BS-3) daha düşüktür. 100 gr SEP içeren numunelerde sıcaklık kürü uygulanması ile su emme kapasiteleri artmıştır. 150 gr SEP içeren numunelerde sıcaklık kürü uygulanması ile su emme kapasiteleri azalmıştır. BS- $2 / 23^{\circ} \mathrm{C} / 150$ gr numunesi en yüksek su emme kapasitesine sahipken sodyum konsantrasyonu artışı ile bu oranda düşüş görülmüştür. Sıcaklık kürü uygulanması numunelerin su emme kapasitelerini azaltan bir etki yapmıştır. Şekil 10'dan görüldüğü üzere uygulanan kür sıcaklığı arttıkça su emme oranlarında artışa neden olmuştur. Çünkü kür sıcaklığının yükselmesi ile numunede bulunan suyun buharlaşması sağlanmış ve numunenin en kuru durumdaki ağırlığ ile doygun haldeki ağırlığı arasındaki fark açılmıştır. SEP'in bünyesindeki su hızlıca harç numune içerisinde salındığından içten kürlenmenin yavaş yavaş gerçekleşmesi engellenmiştir.

Tablo 5. Numunelerin su emme kapasiteleri

\begin{tabular}{|c|c|c|}
\hline $\begin{array}{c}\text { SEP } \\
\text { Oranı (gr) } \\
\end{array}$ & Harç Numuneleri & $\begin{array}{c}\text { Su Emme } \\
\text { Kapasitesi (\%) } \\
\end{array}$ \\
\hline \multirow{6}{*}{0} & $\mathrm{MH}-123^{\circ} \mathrm{C}$ & 9.5 \\
\hline & $\mathrm{MH}-160^{\circ} \mathrm{C}$ & 9.7 \\
\hline & $\mathrm{MH}-223{ }^{\circ} \mathrm{C}$ & 7.8 \\
\hline & $\mathrm{MH}-260^{\circ} \mathrm{C}$ & 7.4 \\
\hline & $\mathrm{MH}-323{ }^{\circ} \mathrm{C}$ & 6.5 \\
\hline & $\mathrm{MH}-360^{\circ} \mathrm{C}$ & 5.6 \\
\hline \multirow{6}{*}{50} & $\mathrm{BS}-1 / 50$ gr SEP / $23^{\circ} \mathrm{C}$ & 10.8 \\
\hline & $\mathrm{BS}-2 / 50$ gr SEP / $23^{\circ} \mathrm{C}$ & 8.5 \\
\hline & $\mathrm{BS}-3 / 50 \mathrm{gr} \mathrm{SEP} / 23^{\circ} \mathrm{C}$ & 8.5 \\
\hline & $\mathrm{BS}-1 / 50$ gr SEP / $60^{\circ} \mathrm{C}$ & 11.7 \\
\hline & $\mathrm{BS}-2 / 50 \mathrm{gr} \mathrm{SEP} / 60^{\circ} \mathrm{C}$ & 7.4 \\
\hline & $\mathrm{BS}-3 / 50$ gr SEP / $60^{\circ} \mathrm{C}$ & 8.4 \\
\hline \multirow{6}{*}{100} & BS- $1 / 100$ gr SEP / $23{ }^{\circ} \mathrm{C}$ & 11.1 \\
\hline & $\mathrm{BS}-2 / 100 \mathrm{gr} \mathrm{SEP} / 23^{\circ} \mathrm{C}$ & 10.5 \\
\hline & $\mathrm{BS}-3 / 100 \mathrm{gr} \mathrm{SEP} / 23^{\circ} \mathrm{C}$ & 9.9 \\
\hline & $\mathrm{BS}-1 / 100 \mathrm{gr} \mathrm{SEP} / 60^{\circ} \mathrm{C}$ & 13.4 \\
\hline & $\mathrm{BS}-2 / 100 \mathrm{gr} \mathrm{SEP} / 60^{\circ} \mathrm{C}$ & 11.9 \\
\hline & $\mathrm{BS}-3 / 100 \mathrm{gr} \mathrm{SEP} / 60^{\circ} \mathrm{C}$ & 10.2 \\
\hline \multirow{6}{*}{150} & $\mathrm{BS}-1 / 150 \mathrm{gr} \mathrm{SEP} / 23{ }^{\circ} \mathrm{C}$ & 16.8 \\
\hline & $\mathrm{BS}-2 / 150 \mathrm{gr} \mathrm{SEP} / 23^{\circ} \mathrm{C}$ & 17.7 \\
\hline & $\mathrm{BS}-3 / 150 \mathrm{gr} \mathrm{SEP} / 23^{\circ} \mathrm{C}$ & 12.4 \\
\hline & BS-1/ 150 gr SEP / $60^{\circ} \mathrm{C}$ & 16.0 \\
\hline & $\mathrm{BS}-2 / 150 \mathrm{gr} \mathrm{SEP} / 60^{\circ} \mathrm{C}$ & 15.9 \\
\hline & $\mathrm{BS}-3 / 150$ gr SEP / $60^{\circ} \mathrm{C}$ & 10.4 \\
\hline
\end{tabular}

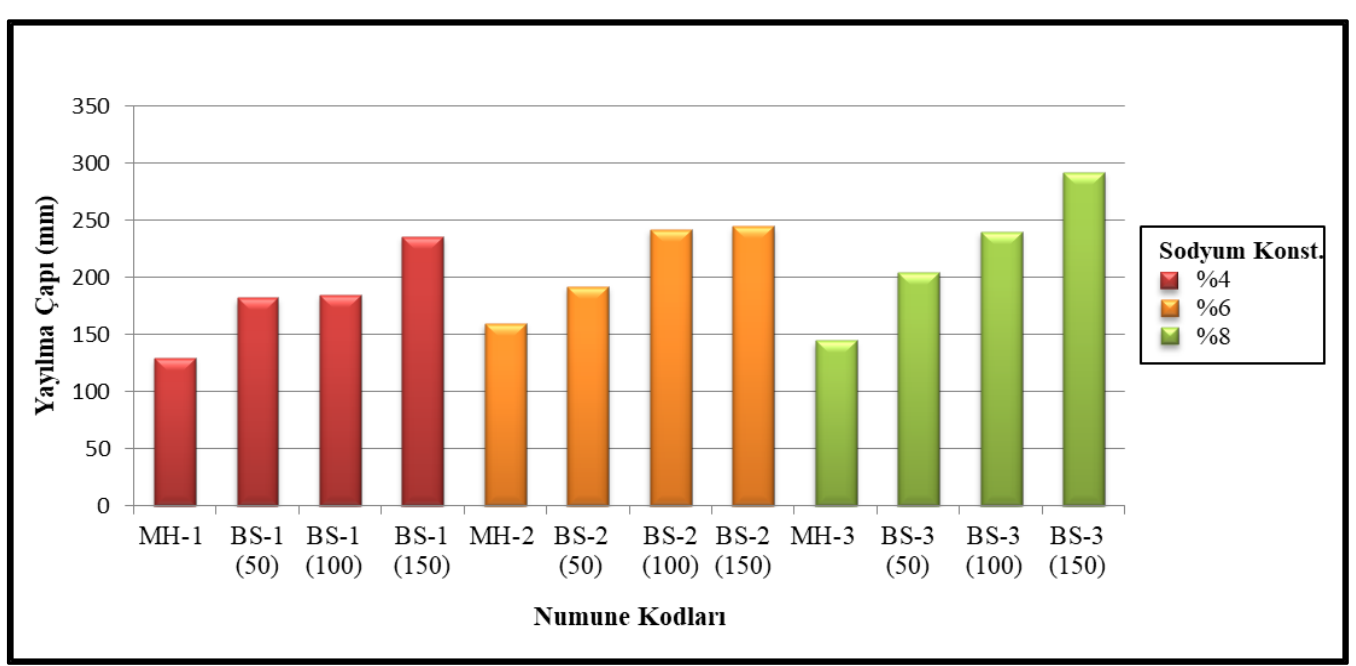

Şekil 9. Taze haldeki karışımların yayılma çapları 


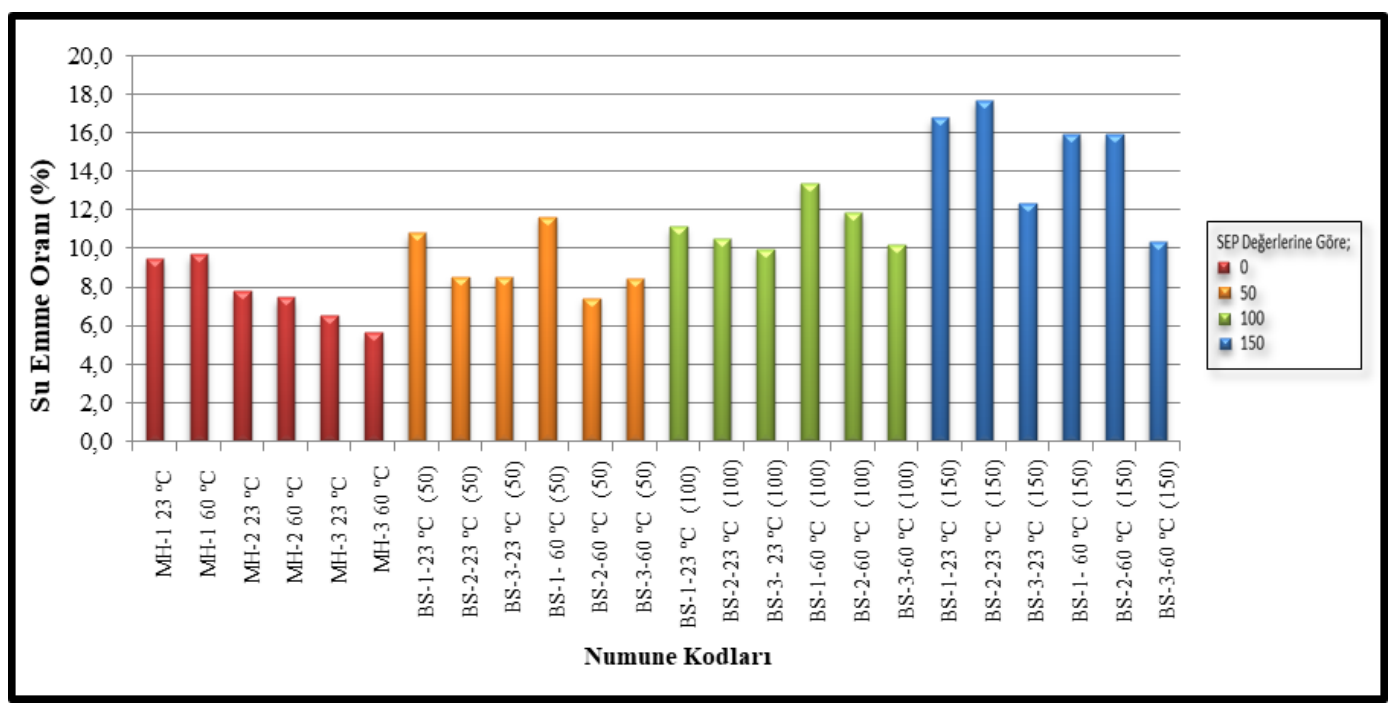

Şekil 10. Referans ve deney numunelerine ait su emme oranları grafiği

Yüksek kür sıcaklığında fırın etkisiyle yaş olan numuneler buharlaşmaya çalışırken, içerisindeki suyun buharlaşma için kendi yolunu bulması sonucu iç çatlaklar oluşur. Bu çatlaklardan giren su miktarına bağlı olarak su emme oranlarında artış olabileceği düşünülmüştür.

$60{ }^{\circ} \mathrm{C}$ sıcaklık küründen çıkarılan numunelerde, içeriğinde düşük oranda SEP içeren ya da hiç SEP içemeyenlerde yüzey çatlaklarının oluştuğu gözlemlenmiştir. Ancak SEP oranı yüksek olan numunelerde bu yüzey çatlaklarının miktarında azalma olduğu görülmüş̧ür. Yani SEP kullanımı ile karışımdaki suyun buharlaşması sonucunda oluşan kuruma çatlaklarının kontrol altına alınabildiği görülmüştür. Snoeck vd. tarafından yapılan çalışmada [14] SEP kullanımı ile çatlak sızdırmazlığının arttığı ifade edilmiştir.

\subsection{Eğilme dayanımı}

Deneysel çalışma sonucu elde edilen verilere göre Şekil 11'deki grafikte de görüleceği üzere SEP oranı arttıkça eğilme dayanımında azalma meydana gelmiştir. 50 gr, 100 gr ve 150 gr SEP ilave edilen numunelerde sıcaklık artışına bağlı olarak \%4 sodyum oranına sahip numunelerin basınç dayanımlarının azaldığı, \%6 sodyum oranındaki numunelerde genel olarak artış gözlendiği (BS2/23/100 gr hariç) ve $\% 8$ sodyum oranına sahip numunelerin değişim göstermeden benzer dayanıma sahip olduğu görülmüştür. Buradan YFC'nin dayanım kazanması için gerekli olan alkali ortamın sodyum konsantrasyonunun en az \%6 olması gerektiği anlaşılmıştır. SEP ilave edilen numunelerin eğilme dayanımları kür sıcaklığına bağlı olarak değişmiştir. Genel olarak $60{ }^{\circ} \mathrm{C}$ kür sicaklığına maruz kalan numunelerin eğilme dayanımları oda sıcaklığında kür edilen numunelere kıyasla daha düşüktür. $\mathrm{Bu}$ durumun nedeninin suyun buharlaşması ya da SEP bünyesindeki suyun yavaş yavaş salınması ile SEP'in kapladığı hacmin küçülmesi neticesinde yerini boşluğa bırakması olarak düşünülmektedir. Boşluklu bir yapının alkali aktivasyonun ilk evrelerinde meydana gelmiş olması numunenin eğilme ve basınç dayanımlarının düşük olmasına sebebiyet vermiştir.
Tablo 6. Numunelerin eğilme dayanımları

\begin{tabular}{|c|c|c|}
\hline $\begin{array}{c}\text { SEP } \\
\text { Oranı (gr) }\end{array}$ & Harç Numuneleri & $\begin{array}{r}\text { Eğilme } \\
\text { Dayanımı } \\
(\mathrm{MPa})\end{array}$ \\
\hline \multirow{6}{*}{0} & $\mathrm{MH}-123^{\circ} \mathrm{C}$ & 2.8 \\
\hline & $\mathrm{MH}-160^{\circ} \mathrm{C}$ & 3.5 \\
\hline & $\mathrm{MH}-223^{\circ} \mathrm{C}$ & 3.4 \\
\hline & $\mathrm{MH}-260^{\circ} \mathrm{C}$ & 3.6 \\
\hline & $\mathrm{MH}-323^{\circ} \mathrm{C}$ & 3.9 \\
\hline & $\mathrm{MH}-360^{\circ} \mathrm{C}$ & 3.9 \\
\hline \multirow{6}{*}{50} & $\mathrm{BS}-1 / 50 \mathrm{gr} \mathrm{SEP} / 23^{\circ} \mathrm{C}$ & 2.0 \\
\hline & $\mathrm{BS}-2 / 50 \mathrm{gr} \mathrm{SEP} / 23^{\circ} \mathrm{C}$ & 3.6 \\
\hline & $\mathrm{BS}-3 / 50 \mathrm{gr} \mathrm{SEP} / 23^{\circ} \mathrm{C}$ & 2.6 \\
\hline & $\mathrm{BS}-1 / 50 \mathrm{gr} \mathrm{SEP} / 60^{\circ} \mathrm{C}$ & 1.8 \\
\hline & $\mathrm{BS}-2 / 50 \mathrm{gr} \mathrm{SEP} / 60^{\circ} \mathrm{C}$ & 4.1 \\
\hline & $\mathrm{BS}-3 / 50 \mathrm{gr} \mathrm{SEP} / 60^{\circ} \mathrm{C}$ & 2.6 \\
\hline \multirow{6}{*}{100} & BS- $1 / 100$ gr SEP $/ 23^{\circ} \mathrm{C}$ & 2.7 \\
\hline & $\mathrm{BS}-2 / 100 \mathrm{gr} \mathrm{SEP} / 23^{\circ} \mathrm{C}$ & 3.4 \\
\hline & $\mathrm{BS}-3 / 100 \mathrm{gr} \mathrm{SEP} / 23^{\circ} \mathrm{C}$ & 3.0 \\
\hline & BS- $1 / 100$ gr SEP $/ 60^{\circ} \mathrm{C}$ & 1.2 \\
\hline & $\mathrm{BS}-2 / 100 \mathrm{gr}$ SEP $/ 60^{\circ} \mathrm{C}$ & 2.6 \\
\hline & BS-3/ $100 \mathrm{gr}$ SEP $/ 60^{\circ} \mathrm{C}$ & 2.9 \\
\hline \multirow{6}{*}{150} & $\mathrm{BS}-1 / 150 \mathrm{gr} \mathrm{SEP} / 23^{\circ} \mathrm{C}$ & 2.1 \\
\hline & $\mathrm{BS}-2 / 150 \mathrm{gr} \mathrm{SEP} / 23^{\circ} \mathrm{C}$ & 1.4 \\
\hline & $\mathrm{BS}-3 / 150 \mathrm{gr} \mathrm{SEP} / 23^{\circ} \mathrm{C}$ & 2.1 \\
\hline & BS- $1 / 150 \mathrm{gr}$ SEP $/ 60^{\circ} \mathrm{C}$ & 1.1 \\
\hline & $\mathrm{BS}-2 / 150 \mathrm{gr} \mathrm{SEP} / 60^{\circ} \mathrm{C}$ & 1.9 \\
\hline & $\mathrm{BS}-3 / 150 \mathrm{gr} \mathrm{SEP} / 60^{\circ} \mathrm{C}$ & 2.1 \\
\hline
\end{tabular}




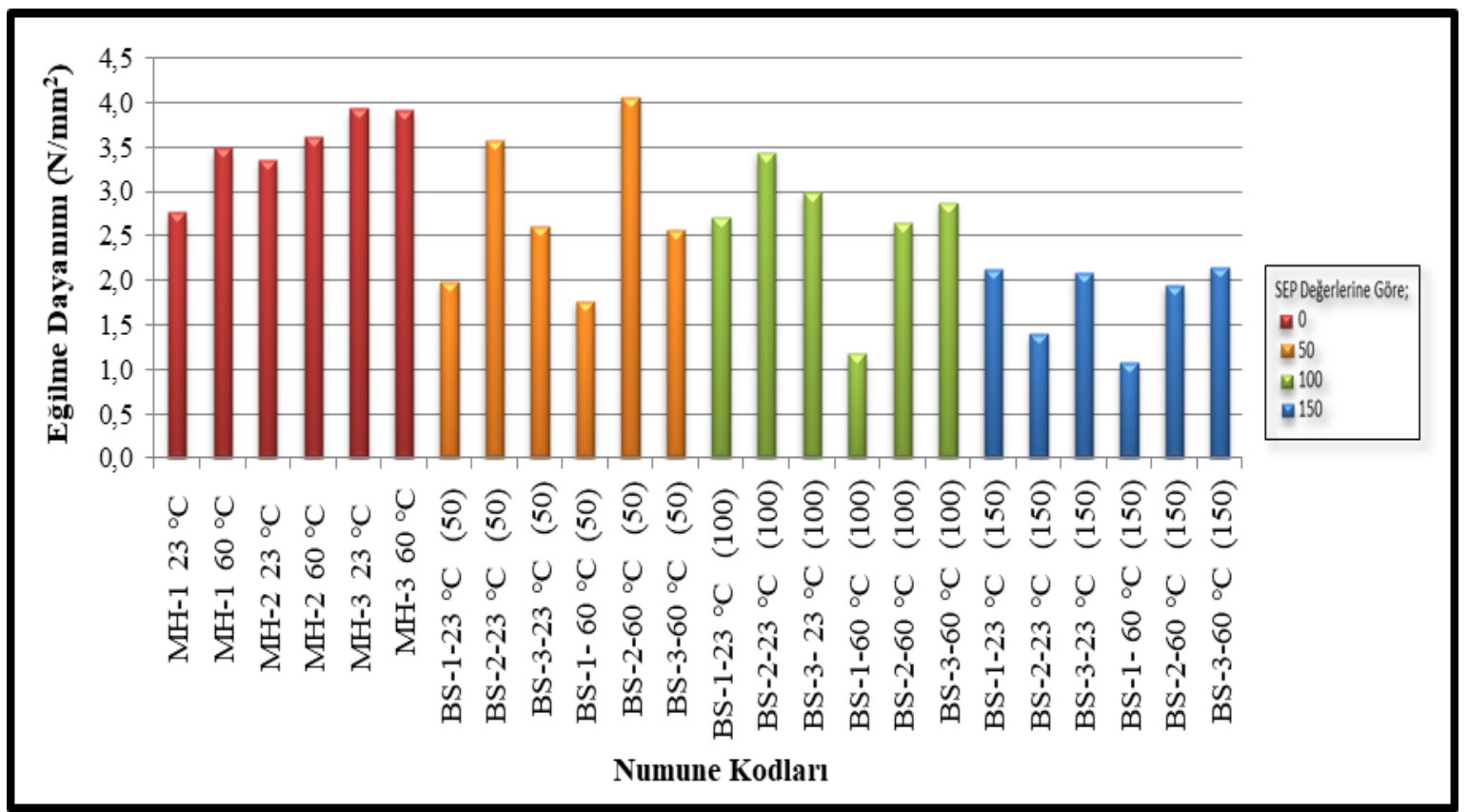

Şekil 11. Referans ve deney numunelerine ait eğilme dayanımı grafiği

SEP miktarına bağlı olarak numune içerisinden ayrılan su miktarı artış gösterdiğinden SEP oranı yüksek olan numunelerin eğilme dayanımları kontrol numunelerine göre kıyaslandığında dayanım farkı artmıştır. SEP oranı düşük olan $\left(50\right.$ gr) $\mathrm{BS}-2 / 23^{\circ} \mathrm{C} / 50$ ve $\mathrm{BS}-2 / 60^{\circ} \mathrm{C} / 50$ numunelerinin eğilme dayanımlarının kontrol numunelerine kıyasla daha yüksek olduğu görülmüştür. Şekil 11'den görüldüğü üzere $\mathrm{BS}-2 / 60^{\circ} \mathrm{C} / 50$ numunesinin eğilme dayanımı 4.1 MPa iken kontrol numunesinin eğilme dayanımı 3.6 MPa'dır. Bu durumun nedeni olarak sicaklık etkisiyle meydana gelen çatlak miktarı SEP'in bünyesindeki suyun yavaş yavaş salınması ile sınırlandırılması olarak düşünülmektedir. Yapılan bir çalışmada SEP katkılı harçlarda suyun salınması ile çatlak oluşumunun gecikmesinden kaynaklı dayanım artışının meydana geldiği ifade edilmiştir [15].

\subsection{Basınç dayanımı}

Basınç dayanımı test sonuçları Tablo 7 ve Şekil 12'de verilmiştir. Kontrol numuneleri ( $\mathrm{MH}-1,2,3)$ incelendiğinde sodyum konsantrasyonu ve kür sıcaklığındaki artış ile basınç dayanımı da artmıştır. Numunelerin içerdikleri SEP miktarı ile dayanım değişimine bakıldığında her üç sodyum konsantrasyonu seviyesinde (\%4, \%6, \%8) SEP miktarı arttıkça basınç dayanımı azalmıştır. SEP miktarındaki artış ile numune içindeki boşluk miktarı da arttığından dolayı basınç dayanımı da önemli ölçüde azaltmıştır. Bu azalma her iki kür sıcaklığı içinde geçerli olmuştur. Yapılan bir çalışmada, SEP içeren karışımların basınç dayanımlarının aynı yaştaki referans numunelere göre daha düşük olduğu ifade edilmiştir. Durumun nedeni SEP katkısı ile sertleştirilmiş harçlardaki makro gözeneklerin oluşumu ve boşluk miktarının artmasının sonucu olarak gösterilmiştir $[15,16]$.
$\% 4$ sodyum konsantrasyonuna sahip numunelerin $50 \mathrm{gr}$ ve 100 gr SEP içerenlerinde sıcaklıkla birlikte dayanımda azalma meydana gelmişken, 150 gr SEP içeren numunelerde tersi bir davranış gerçekleştirmiştir. 150 gr SEP içeren numunelerin yüksek kür sıcaklığında daha fazla dayanım kazanmıştır. $\mathrm{Bu}$ durumun nedeninin SEP bünyesinde bulunan suyun harç içerisine salınımı ile büzülme çatlaklarının önlenmesi ve mikro çatlakların sınırlandırılması ile hidratasyonun gelişimine katkı sağlanması olarak düşünülmektedir. Sodyum konsantrasyonu \%6'nın üzerinde çıkarıldığında (\%8) kür sıcaklığının $23{ }^{\circ} \mathrm{C}$ 'den $60^{\circ} \mathrm{C}$ 'ye yükseltilmesi 50 gr SEP içeren numunelerde dayanıma önemli bir etki yapmamıştır. 100 gr ve 150 gr SEP oranlarında ise sıcaklık artışı ile basınç dayanımı artmıştır. BS-1/23 ${ }^{\circ} \mathrm{C} / 150$ gr'lik numune en düşük dayanıma $(0.9 \mathrm{MPa})$ sahip iken $\mathrm{BS}-2 / 60{ }^{\circ} \mathrm{C} / 50 \mathrm{gr}$ numunesinin basınç dayanımı $(26.8 \mathrm{MPa})$ en yüksektir. Buna en yakın basınç dayanımı ortam sıcaklığında kür edilen $\mathrm{BS} 2 / 23{ }^{\circ} \mathrm{C} / 100$ gr numunesidir $(22.8 \mathrm{MPa})$. Bu dayanım değerleri hiç SEP içermeyen kontrol numuneleri ile kıyaslanabilir durumdadır. Birçok alanda boşluklu ve yüksek mukavemetli harçlara ihtiyaç duyulmaktadır. Yapılarda kullanım amacıyla üretilen harç ya da betonların boşluklu olması ile birlikte ağırlığında azalma meydana gelir. Hafif yapı elemanlarının kullanılması ile binanın ölü yükü azaldığından kesit küçülmesi ve donatı alanından tasarruf sağlanır [17]. Ayrıca boşluk miktarının çok olmasından dolayı 1sıyı iletme kabiliyeti azalacağından termal yalıtım özelliği sayesinde enerji tasarrufu sağlamak da getiriler arasında olmaktadır [18]. Bu tür yap1 elemanlarına ihtiyaç duyulmaktadır. Böylece boşluk oranı ve basınç dayanımı yüksek harç numunelerin üretilebilir olduğu belirlenmiştir. 
Tablo 7. Numunelerin basınç dayanımları

\begin{tabular}{|c|c|c|}
\hline $\begin{array}{c}\text { SEP } \\
\text { Oranı (gr) }\end{array}$ & Harç Numuneleri & $\begin{array}{r}\text { Basınç } \\
\text { Dayanımı } \\
(\mathrm{MPa}) \\
\end{array}$ \\
\hline \multirow{6}{*}{0} & $\mathrm{MH}-123^{\circ} \mathrm{C}$ & 15.4 \\
\hline & $\mathrm{MH}-160^{\circ} \mathrm{C}$ & 18.9 \\
\hline & $\mathrm{MH}-223^{\circ} \mathrm{C}$ & 26.6 \\
\hline & $\mathrm{MH}-260^{\circ} \mathrm{C}$ & 29.0 \\
\hline & $\mathrm{MH}-323^{\circ} \mathrm{C}$ & 30.4 \\
\hline & $\mathrm{MH}-360^{\circ} \mathrm{C}$ & 33.3 \\
\hline \multirow{6}{*}{50} & BS- $1 / 50$ gr SEP / $23^{\circ} \mathrm{C}$ & 7.5 \\
\hline & $\mathrm{BS}-2 / 50 \mathrm{gr} \mathrm{SEP} / 23^{\circ} \mathrm{C}$ & 22.8 \\
\hline & $\mathrm{BS}-3 / 50 \mathrm{gr} \mathrm{SEP} / 23^{\circ} \mathrm{C}$ & 16.3 \\
\hline & BS- $1 / 50$ gr SEP / $60^{\circ} \mathrm{C}$ & 3.8 \\
\hline & $\mathrm{BS}-2 / 50 \mathrm{gr} \mathrm{SEP} / 60^{\circ} \mathrm{C}$ & 26.8 \\
\hline & BS-3/ 50 gr SEP / $60^{\circ} \mathrm{C}$ & 17.2 \\
\hline \multirow{6}{*}{100} & BS- $1 / 100$ gr SEP $/ 23^{\circ} \mathrm{C}$ & 10.6 \\
\hline & $\mathrm{BS}-2 / 100 \mathrm{gr} \mathrm{SEP} / 23^{\circ} \mathrm{C}$ & 18.4 \\
\hline & $\mathrm{BS}-3 / 100 \mathrm{gr} \mathrm{SEP} / 23^{\circ} \mathrm{C}$ & 12.0 \\
\hline & BS- $1 / 100$ gr SEP / $60^{\circ} \mathrm{C}$ & 4.1 \\
\hline & $\mathrm{BS}-2 / 100 \mathrm{gr} \mathrm{SEP} / 60^{\circ} \mathrm{C}$ & 13.8 \\
\hline & BS-3/ $100 \mathrm{gr}$ SEP $/ 60^{\circ} \mathrm{C}$ & 15.6 \\
\hline \multirow{6}{*}{150} & $\mathrm{BS}-1 / 150 \mathrm{gr}$ SEP $/ 23^{\circ} \mathrm{C}$ & 0.9 \\
\hline & BS- $2 / 150 \mathrm{gr} \mathrm{SEP} / 23^{\circ} \mathrm{C}$ & 4.8 \\
\hline & $\mathrm{BS}-3 / 150 \mathrm{gr} \mathrm{SEP} / 23^{\circ} \mathrm{C}$ & 13.0 \\
\hline & $\mathrm{BS}-1 / 150 \mathrm{gr} \mathrm{SEP} / 60^{\circ} \mathrm{C}$ & 2.1 \\
\hline & $\mathrm{BS}-2 / 150 \mathrm{gr} \mathrm{SEP} / 60^{\circ} \mathrm{C}$ & 6.6 \\
\hline & $\mathrm{BS}-3 / 150$ gr SEP $/ 60^{\circ} \mathrm{C}$ & 9.9 \\
\hline
\end{tabular}

\subsection{Eğilme-basınç dayanımı}

50, 100, 150 gr SEP katkısı ile hazırlanan numunelerin kontrol numunelerine kıyasla eğilme-basınç dayanımları arasındaki ilişkiyi gösteren Şekil 13'deki grafikte referans numunelerinin tamamı eğilme dayanımı bakımından 2.5-4 $\mathrm{MPa}$ aralığında iken, basınç dayanımları 15-35 $\mathrm{MPa}$ aralığındadır. Tüm kontrol numunelerinde eğilme dayanımları artarken genel olarak sıcaklığa bağlı basınç dayanımları da artmıştır. Genel olarak SEP oranı arttıkça hem eğilme hem de basınç dayanımlarının azaldığı ve bunun nedeninin artan boşluk miktarı olduğu düşünülmektedir. 60 ${ }^{\circ} \mathrm{C}$ 'lik numunelerin dayanımı oda sıcaklığındaki numunelere göre daha düşük değerlerde seyretmektedir. Sıcaklık kürü sebebi ile meydana gelen çatlaklar için 50 gr SEP ilavesi ile bünyesindeki suyu karışıma salması ile önlenebilmiştir. Böylece hem eğilme hem de basınç dayanımı yüksek alkali aktive edilmiş YFC'li harç üretimleri yapılabilmiştir.

\subsection{Su Emme-basınç dayanımı}

Farklı oranlarda SEP ilavesi ile hazırlanan numunelerin su emme kapasitesi ve basınç dayanımı arasındaki ilişki Şekil 14'de gösterilmiştir. Basınç dayanımı ile su emme kapasiteleri arasında ters bir ilişki bulunmaktadır. SEP oranı arttıkça numunelerin su emme kapasiteleri de artmış ancak basınç dayanımları azalmıştır. Bunun asıl nedeni polimerin harçta oluşturduğu boşluk yapısıdır. Boşlukların artmasıyla harcın basınç etkilerine karşı gösterdiği direnç azalır [19].

Song vd. [20] yaptığ 1 çalışmada; SEP arttıkça içten kürlemenin etkisinin arttığını; bununla birlikte SEP'ın, numuneler içinde basınç dayanımını azaltan boşluklar yarattığını ve SEP'lerin uygun dozajını belirlemek için, numunelerin mukavemetinin artması ve azalması dikkate alınması gerekildiği belirtilmiştir. 150 gr katkı içeren numuneler incelendiğinde, boşluk oranı arttıkça su emme oranları da artan numunelerde dayanım oldukça düşmüştür.

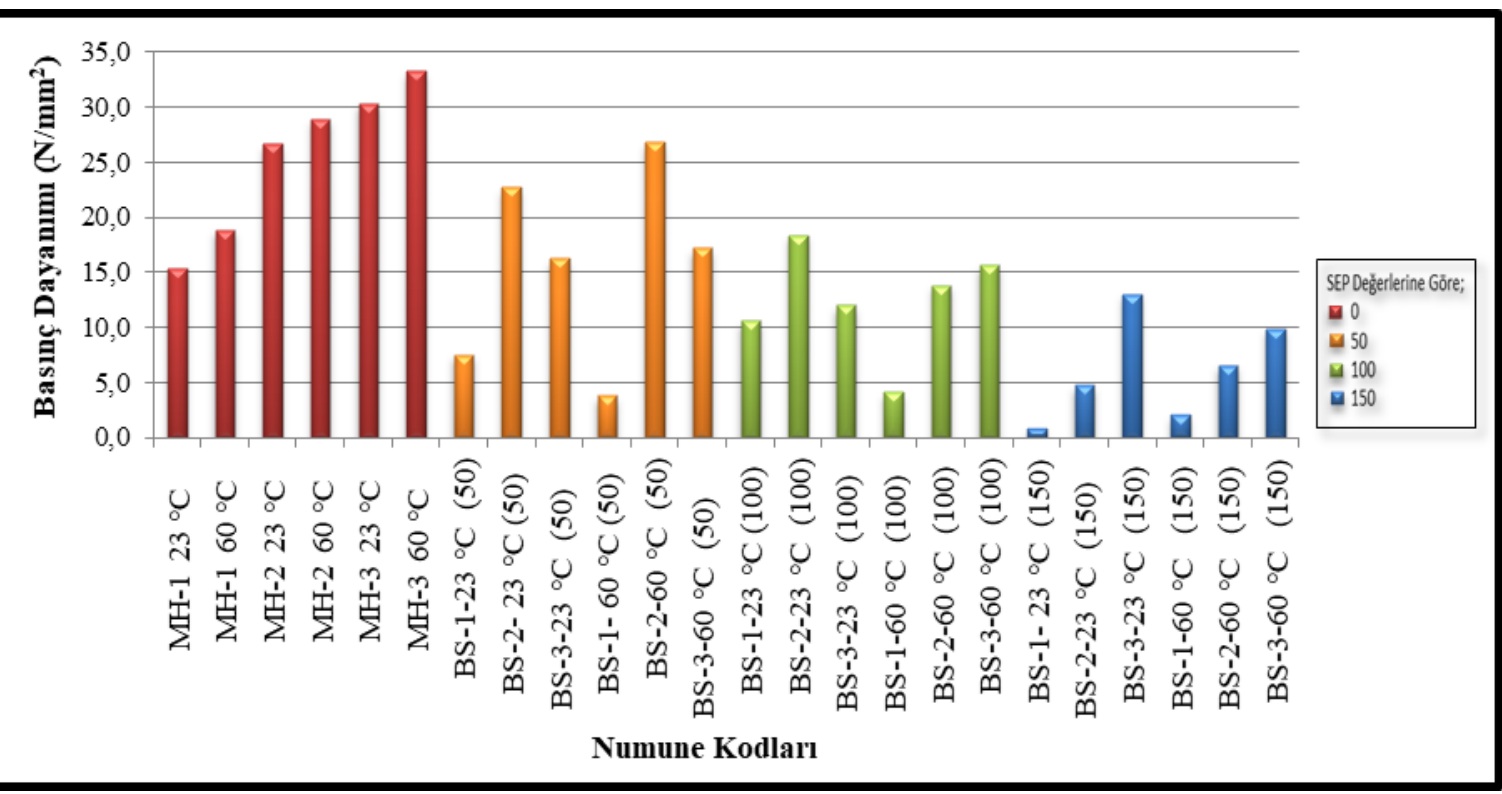

Şekil 12. Numunelerin basınç dayanımları 


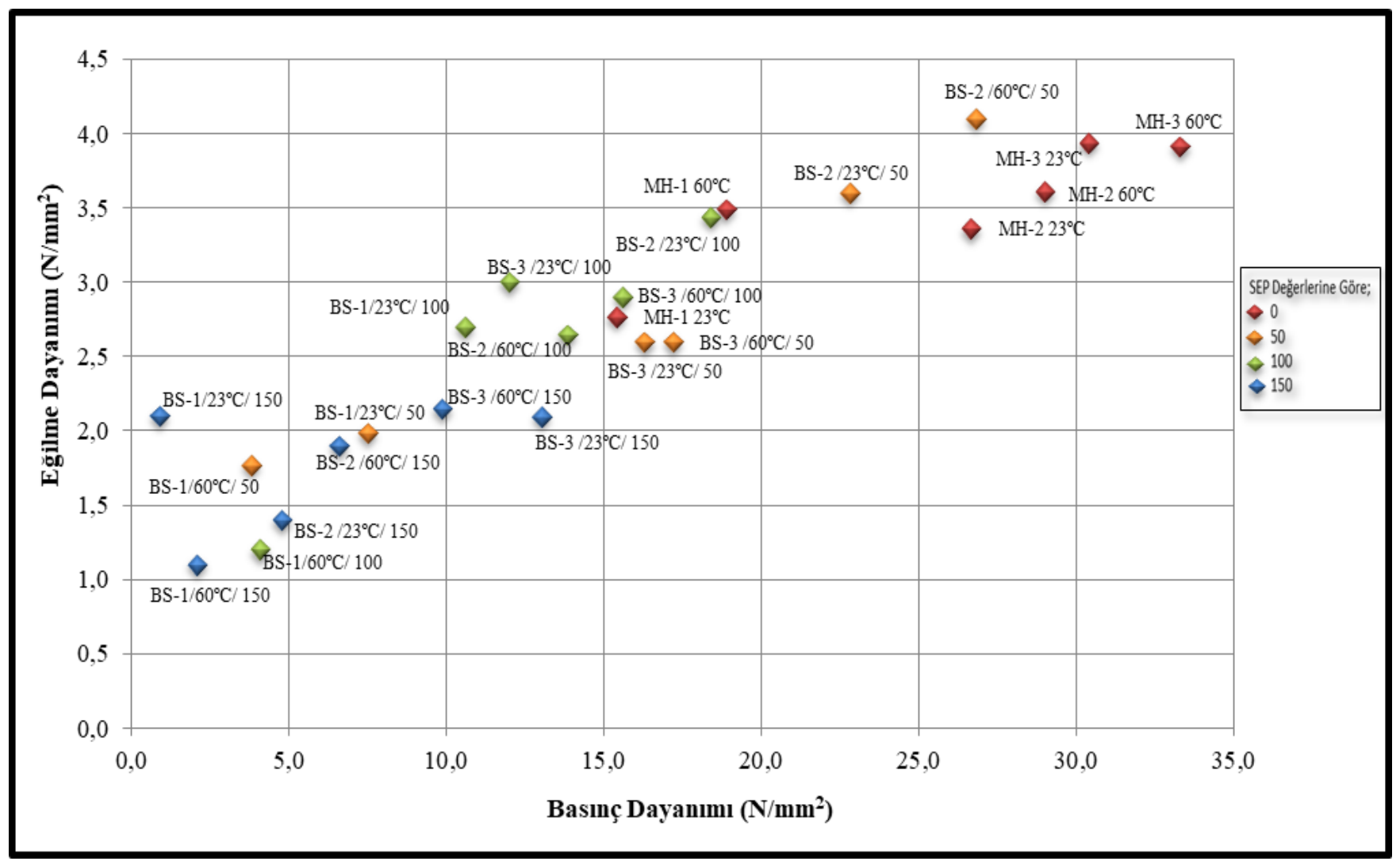

Şekil 13. Numunelerin eğilme dayanımı ile basınç dayanımı arasındaki ilişki

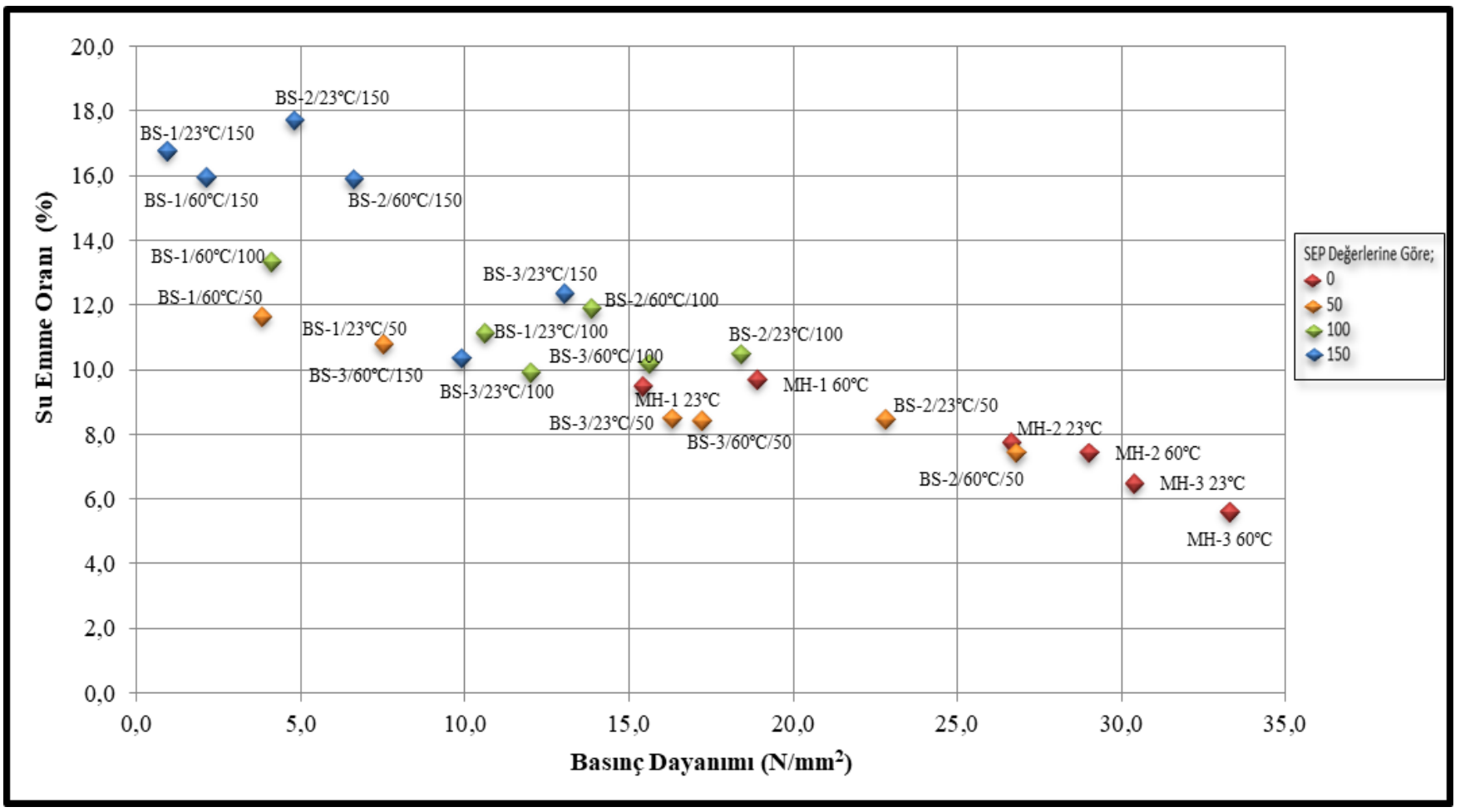

Şekil 14. Numunelerin su emme kapasitesi ile basınç dayanımı arasındaki ilişki 


\section{Sonuçlar}

Alkaliler ile aktive edilen YFC harçlarının SEP ilave edilmesi ile içten kürlenme, işlenebilirlik ve dayanım özelliklerini incelemek amacıyla yapılan deneysel çalışma sonucunda elde edilen sonuçlar şöyledir:

- SEP katkısı alkalilerle aktive edilen YFC harçlarının su emme kapasitelerini arttırmış ancak alkali konsantrasyonu ve kür koşullarının uygun olduğu karışımlarda dayanımda önemli bir azalma meydana gelmemiştir.

- $\% 4$ ve $\% 8$ sodyum konsantrasyonu ile aktive edilen YFC harçlarında kontrol numunelerine oranla dayanım değerlerinin önemli derecede azaldığı ancak \%6 sodyum konsantrasyonuna sahip numunelerin dayanım açısından kontrol numuneleri ile kıyaslanabilir olduğu görülmüştür.

- SEP ilave oranı arttıkça taze haldeki harcın yayılma çapı artmıştır.

- 150 gr SEP katkısı ile üretilen numunelerde gözlemlenen kuruma çatlakları önemli ölçüde azalmıştır. SEP kullanımı ile içten kürlenme etkisi gerçekleşmiştir.

- Sicaklık kürü uygulanan numunelerde gözlenen yüzey çatlak sayısının ve çatlak boyutunun SEP ilavesi yapılan numunelerde azaldığı gözlenmiştir.

- SEP miktarının 100 gr'den fazla olması durumunda eğilme ve basınç dayanımlarında ciddi oranda azalma meydana gelmiştir. SEP miktarı 150 gr'yi aştıktan sonra segregasyon ve kusmaya neden olmuştur ve daha yüksek oranlarda SEP içeren harç üretimleri yapılamamıştır.

- Dayanım ve su emme kapasitesinin her ikisininde yüksek olduğu ideal karışım şartları BS2 /50 gr $60{ }^{\circ} \mathrm{C}$ olarak belirlenmiştir.

YFC'nin alkali aktivasyonunda SEP kullanımı ile içten kürlenme sağlanarak zaman ve enerji tasarrufu yüksek, sürdürülebilir geopolimerler üretilebilir.

\section{Çıkar çatışması}

Yazarlar çıkar çatışması olmadığını beyan etmektedir.

\section{Benzerlik oranı (iThenticate): \%12}

\section{Kaynaklar}

[1] S. Aydin, Alkalilerle aktive edilmiş yüksek firın cürufu bağlayıcılı lifli kompozit geliştirilmesi. Doktora Tezi, Dokuz Eylül Üniversitesi Fen Bilimleri Enstitüsü, Türkiye, 2010.

[2] Çevre ve Şehircilik Bakanlığı, Demir Çelik Cüruf Raporu. Türkiye Çelik Üreticileri Derneği,2015.

[3] X. Chen, L.S. Chen, J.T. Xu, Research on sodium polyacrylate and its effects on mechanical properties of slag-based geopolymer. In Applied Mechanics and Materials Trans Tech Publications Ltd., 638, 13871390,2014. https://doi.org/10.4028/www.scientific.net/ AMM.638-640.1387

[4] M. Al-Nasra, Concrete made for energy conservation mixed with sodium polyacrylates. International Journal of Engineering Research and Application, 3(5) 601-13, 2013.

[5] M. Al-Nasra, M. Daoud, Investigating the use of super absorbent polymer in plain concrete. International Journal of Emerging Technology and Advanced Engineering,3(8) 598-603, 2013.

[6] T. Manzur, S. Iffat and M. A. Noor, Efficiency of sodium polyacrylate to improve durability of concrete under adverse curing condition, Advances in Materials Science and Engineering. Article ID 685785, 2015. https://doi.org/10.1155/2015/685785.

[7] O. Mahmut, M. Emiroğlu, Elazığ ferrokrom cürufunun alkali aktive edilmiş harç üretiminde kullanım potansiyelinin araștırılması. Fırat Üniversitesi Mühendislik Bilimleri Dergisi, 28(1), 23-34, 2016.

[8] E. Ekinci, İ. Türkmen, Farklı aktivatör ve ham madde değişkenlerinin geopolimer hamurun basınç dayanımına etkisinin incelenmesi. Avrupa Bilim ve Teknoloji Dergisi,(24),169-175,2021. https://doi.org/ 10.31590/ejosat.903895.

[9] Z. He, A. Shen, Y. Guo, Z. Lyu, D. Li, X. Qin, M. Zhao and Z. Wang, Cement-based materials modified with superabsorbent polymers: A review. Construction and Building Materials, 225, 569-590, 2019. https://doi.org/10.1016/j.conbuildmat.2019.07.139

[10] C. Elibol, Alkalilerle aktive edilen çimento esaslı malzemelerin basınç dayanımlarının incelenmesi. Yüksek Lisans Tezi, İstanbul Teknik Üniversitesi Fen Bilimleri Enstitüsü, Türkiye, 2012.

[11] H.T. Türker, M. Balçikanli, İ.H. Durmuş, E. Özbay and M. Erdemir, Microstructural alteration of alkali activated slag mortars depend on exposed high temperature level. Construction and Building Materials, 104, 169-180, 2016.

[12] ASTM C109 Standard Test Method for Compressize Strength of Hydraulic Cement Mortar, 1993 Annual Book of ASTM Standards, ASTM, 1916 Race Steet, Philadelphia, PA 19103.

[13] TS EN 196-1. "Çimento deney metotlar1- Bölüm 1: Dayanım". Türk Standartları Enstitüsü, 2002.

[14] D. Snoeck, K. Van Tittelboom, S. Steuperaert, P. Dubruel and N. De Belie, Self-healing cementitious materials by the combination of microfibres and superabsorbent polymers. Journal of Intelligent Material Systems and Structures,25(1), 13-24, 2014. https://doi.org/10.1177/1045389X12438623

[15] L. De Meyst, E. Mannekens, K. Van Tittelboom, \& N. De Belie, The influence of superabsorbent polymers (SAPs) on autogenous shrinkage in cement paste, mortar and concrete. Construction and Building Materials, 286, 122948, 2021.

[16] De Cycloaddition, U. D. L. R., Guillaume TILLET (Doctoral dissertation, Université Claude BernardLyon), 2010.

[17] O. A. Düzgün, R. Gül, ve A.C. Aydın, Effect of steel fibers on the mechanical properties of natural lightweight aggregate concrete. Materials Letters, 59:3357-3363, 2005. 
[18] N. Kabay, Hafif agregalı betonun boşluk yapısının mekanik ve fiziksel özelliklere etkisi. Yıldız Teknik Üniversitesi, Fen Bilimleri Enstitüsü, Doktora tezi, 2009.

[19] T.F Awolusi, L.O Oke, O.O Akinkurolere, D.P. Ubani, R.T. Bamisaye, \& O.G Aluko, The application of response surface methodology in understanding the compressive strength and water absorption capacity of sandcrete blocks. Silicon, 1-10,2020.
[20] C. Song, Y.C. Choi and S. Choi, Effect of internal curing by superabsorbent polymers-internal relative humidity and autogenous shrinkage of alkali-activated slag mortars. Construction and Building Materials,123,198-206,2016.https://doi.org/ 10.1016/j.conbuildmat.2016.07.007 